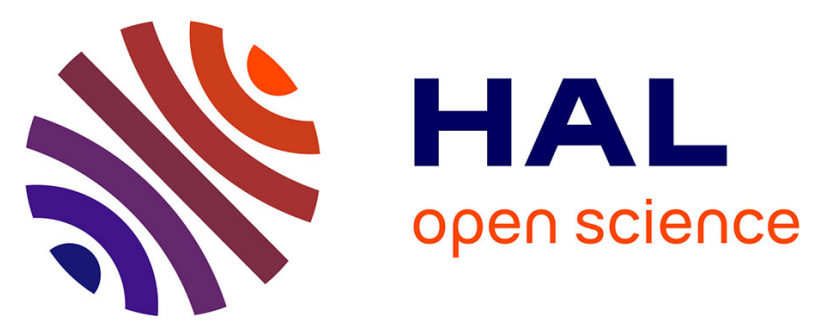

\title{
Quantitative food web modeling unravels the importance of the microphytobenthos-meiofauna pathway for a high trophic transfer by meiofauna in soft-bottom intertidal food webs
}

Luuk Hendrikus van Der Heijden, Nathalie Niquil, M. Haraldsson, R.M. Asmus, S.R. Pacella, M. Graeve, J. Rzeznik-Orignac, H. Asmus, B. Saint-Béat, B. Lebreton

\section{- To cite this version:}

Luuk Hendrikus van Der Heijden, Nathalie Niquil, M. Haraldsson, R.M. Asmus, S.R. Pacella, et al.. Quantitative food web modeling unravels the importance of the microphytobenthos-meiofauna pathway for a high trophic transfer by meiofauna in soft-bottom intertidal food webs. Ecological Modelling, 2020, 430, 10.1016/j.ecolmodel.2020.109129 . hal-02890326

\author{
HAL Id: hal-02890326 \\ https://hal.science/hal-02890326
}

Submitted on 15 Dec 2020

HAL is a multi-disciplinary open access archive for the deposit and dissemination of scientific research documents, whether they are published or not. The documents may come from teaching and research institutions in France or abroad, or from public or private research centers.
L'archive ouverte pluridisciplinaire HAL, est destinée au dépôt et à la diffusion de documents scientifiques de niveau recherche, publiés ou non, émanant des établissements d'enseignement et de recherche français ou étrangers, des laboratoires publics ou privés. 
1 Quantitative food web modeling unravels the importance of the

2 microphytobenthos-meiofauna pathway for a high trophic transfer by

3

4

5

6

7

8

9

10

11

12 meiofauna in soft-bottom intertidal food webs.

L.H. van der Heijden ${ }^{1,2, *}$, N. Niquil ${ }^{3}$, M. Haraldsson ${ }^{3,4,5}$, R.M. Asmus ${ }^{2}$, S.R. Pacella ${ }^{6}$, M. Graeve ${ }^{7}$ J. Rzeznik-Orignac $^{8}$, H. Asmus ${ }^{2}$, B. Saint-Béat ${ }^{9}$, B. Lebreton ${ }^{1}$

${ }^{1}$ UMR 7266 Littoral, Environnement et Sociétés (CNRS - University of La Rochelle), Institut du littoral et de l'environnement, 2 rue Olympe de Gouges, 17000 La Rochelle, France

${ }^{2}$ Alfred-Wegener-Institut Helmholtz-Zentrum für Polar- und Meeresforschung, Wattenmeerstation Sylt, Hafenstrasse 43, 25992 List/Sylt, Germany

${ }^{3}$ Centre National de la Recherche Scientifique (CNRS)/University of Caen Normandy, BOREA (MNHN, IRD, UA, SU), 14032 Caen, France

${ }^{4}$ Department of Marine Sciences, University of Gothenburg, Box 461, SE-405 30 Göteborg, Sweden ${ }^{5}$ Sorbonne Université, Université Paris Est Créteil, Université Paris Diderot, CNRS, INRA, IRD, Institute of Ecology and Environmental sciences - Paris, IEES-Paris, 75005 Paris, France

${ }^{6}$ Pacific Ecological Systems Division, Center for Public Health and Environmental Assessment, Office of Research and Development, United States Environmental Protection Agency, Newport, OR 97365, USA

${ }^{7}$ Alfred Wegener Institut Helmholtz Centre for Polar- and Marine Research, Bremerhaven, Germany ${ }^{8}$ Sorbonne Université, UPMC Univ Paris 06, CNRS, Laboratoire d'Ecogéochimie des Environnements Benthiques (LECOB UMR 8222), Observatoire Océanologique, 66650 Banyuls/Mer, France

${ }^{9}$ Québec-Océan and Takuvik, Département de Biologie, Université Laval, Québec City, QC, Canada

* Corresponding author:

L.H. van der Heijden

Email address: vanderheijden.lh@gmail.com

Declaration of interest: none 
ABSTRACT

Meiofauna are known to have an important role on many ecological processes, although, their role in food web dynamics is often poorly understood, partially as they have been an overlooked and under sampled organism group. Here, we used quantitative food web modeling to evaluate the trophic relationship between meiofauna and their food sources and how meiofauna can mediate the carbon flow to higher trophic levels in five contrasting soft-bottom intertidal habitats (including seagrass beds, mudflats and sandflats). Carbon flow networks were constructed using the linear inverse model-Markov chain Monte Carlo technique, with increased resolution of the meiofauna compartments (i.e. biomass and feeding ecology of the different trophic groups of meiofauna) compared to most previous modeling studies. These models highlighted that the flows between the highly productive microphytobenthos and the meiofauna compartments play an important role in transferring carbon to the higher trophic levels, typically more efficiently so than macrofauna. The pathway from microphytobenthos to meiofauna represented the largest flow in all habitats and resulted in high production of meiofauna independent of habitat. All trophic groups of meiofauna, except for selective deposit feeders, had a very high dependency on microphytobenthos. Selective deposit feeders relied instead on a wider range of food sources, with varying contributions of bacteria, microphytobenthos and sediment organic matter. Ecological network analyses (e.g. cycling, throughput and ascendency) of the modeled systems highlighted the close positive relationship between the food web efficiency and the assimilation of high-quality food sources by primary consumers, e.g. meiofauna and macrofauna. Large proportions of these flows can be attributed to trophic groups of meiofauna. The sensitivity of the network properties to the representation of meiofauna in the models leads to recommending a greater attention in ecological data monitoring and integrating meiofauna into food web models.

Keywords: food web model; linear inverse model; meiofauna; microphytobenthos; stable isotope mixing models; intertidal habitats 


\section{Introduction}

Meiofauna have been poorly considered in the last decades when assessing functioning of coastal and marine ecosystems (Moens et al., 2011; Schratzberger and Ingels, 2018), e.g. roles in trophic processes, energy flows (Leguerrier et al., 2003; Moens et al., 2013). This lack of interest is likely related to the belief that meiofauna were a "trophic dead end" (Heip and Smol, 1975; McIntyre and Murison, 1973), and to the methodological issues when studying them, due to their small size (Carman and Fry, 2002; Moens et al., 2005). Methodological improvements (Leduc et al., 2009; Vafeiadou et al., 2014) led to a better perception of meiofauna in the functioning of ecosystems (Coull, 1990; Leguerrier et al., 2003), weakening the "trophic dead end" hypothesis. For example, in intertidal and deep-sea ecosystems, the metabolic importance of meiofauna can sometimes overtake that of macrofauna - a compartment which has been highly studied unlike meiofauna-(Giere, 2009; Schwinghamer et al., 1986) with meiofauna's metabolic rate being reported 21 times higher than that of macrofauna in a tidal flat (Kuipers et al., 1981). Nowadays meiofauna are known to take part in many ecological functions, e.g., sediment stabilization, biochemical cycling and food web dynamics (Schratzberger and Ingels, 2018). A better comprehension of ecological functions of meiofauna in coastal food webs requires considering meiofauna at the ecosystem scale, following a holistic approach. Indeed, because meiofauna mediates flows of organic matter between primary producers and higher trophic level consumers (Leguerrier et al., 2003; Pascal et al., 2019), assessments about the role of meiofauna should consider two aspects: (1) the interaction between meiofauna and their food sources and (2) the fate of meiofauna.

Interactions between meiofauna and their resources are complex due to the large variety of potential food sources (e.g. microalgae, detrital matter, bacteria; Lebreton et al., 2012; Moens et al., 2005; Vafeiadou et al., 2014) and quantifications of carbon fluxes from lower trophic levels to meiofauna are scarce (Danovaro et al., 2002; van Oevelen et al., 2006). In bare sediment systems, meiofauna have been reported to feed mainly on microphytobenthos (Moens et al., 2014; RzeznikOrignac et al., 2008), whereas their range of food sources is much larger in vegetated sediments (Lebreton et al., 2012; Leduc et al., 2009; Vafeiadou et al., 2014). Nematodes, generally the most abundant taxon of meiofauna, have a very diverse feeding behavior, i.e., herbivory, bacterivory, or omnivory/carnivory (Wieser, 1953), and can be classified into various trophic groups. Feeding behavior and abundances of nematodes from these trophic groups might change depending on availability, quantity and quality of food sources (Giere, 2009; Moens et al., 2013). Non-selective deposit feeders for example feed on various food sources such as microphytobenthos, bacteria and detritus, and their diet changes depending on the availability of these food sources (Moens and Vincx, 1997a; Rzeznik-Orignac et al., 2008). It has also been demonstrated that meiofauna, especially benthic copepods, may control microphytobenthos biomass (Blanchard, 1991; Montagna et al., 1995) as well 
as transfer carbon from bacterial communities towards higher trophic levels (Pascal et al., 2008; Vafeiadou et al., 2014).

Many unknowns remain about the fate of meiofauna in benthic food webs. For a long time there was a controversy about the fate of meiofauna in benthic food webs (Heip et al., 1992), whether meiofauna was a dead end in the food web (Heip and Smol, 1975; McIntyre and Murison, 1973), or an important link between primary producers and higher trophic levels (Coull, 1990; Schückel and Kröncke, 2013). Meiofauna production is high (from 4 to $29 \mathrm{gC} \mathrm{m}^{-2}$ year-1 ${ }^{-1}$ Chardy and Dauvin, 1992; Danovaro et al., 2002) due to their elevated turnover rate (Kuipers et al., 1981), despite their general relatively low biomass. Their nutritional quality, i.e. calories (Sikora et al., 1977), low carbon/nitrogen ratios (Couch, 1989), high levels of amino acids (Vilela, 1992; Watanabe et al., 1978) and essential fatty acids (Watanabe et al., 1983), are sufficient to fulfill a predator's needs (Coull, 1999), explaining their preference as prey for higher trophic levels (Danovaro et al., 2007). However, knowledge about carbon fluxes from meiofauna to higher trophic levels and determination of their transfer efficiency remain scarce (Danovaro et al., 2002; Schratzberger and Ingels, 2018). Danovaro et al. (2007) estimated that more than $75 \%$ of the total meiofauna production is channeled to higher trophic levels in soft-bottom habitats. However, meiofauna consists of a diversity of organisms which have different feeding strategies (i.e. trophic groups; Wieser, 1953). The fate of these trophic groups in food webs most likely varies due to their relative biomasses among meiofauna, which can differ a lot between habitats (van der Heijden et al., 2018), and due to high variability and selective feeding on this meiofauna by higher trophic levels (Magnhagen et al., 2007; Schückel et al., 2013). Therefore, there is a need to consider meiofauna trophic groups in food web assessments, and inter-habitat comparison can help at understanding how changes in trophic groups' biomass affect the role of meiofauna in coastal food webs.

Linear inverse modeling is a useful tool to describe the functioning of a food web at the habitat or the ecosystem scale (Baird et al., 2007; Leguerrier et al., 2007). It generates a static, mass-balanced, temporally integrated snapshot of the complete food web and its flows using a combination of field and relevant literature data (Niquil et al., 2011; Vézina and Platt, 1988) and it is a powerful method in estimating unmeasured flows within an ecosystem (Degré et al., 2006; Leguerrier et al., 2003; Pacella et al., 2013). Combined with the Markov chain Monte Carlo method, it provides the probability distribution of flows in underdetermined systems and avoids underestimations in both the size and complexity of the modeled food web (Johnson et al., 2009; Kones et al., 2006). Based on the estimated flow-networks, several food web characteristics can be defined, such as efficiencies, recycling and dependencies (Niquil et al., 2011), which can in turn be useful in ecosystem management and policy making (de la Vega et al., 2018; Schückel et al., 2018). One of these food web characteristics, the efficiency with which carbon energy is transferred and assimilated, can be linked to the quality and 
quantity of primary food sources (Marcarelli et al., 2011). The lower trophic levels of food webs (e.g. meiofauna and macrofauna) have the strongest response to changes in food quality whereas the highest trophic levels (i.e. omnivores/carnivores) seem more dependent on the food quantity (Campanyà-Llovet et al., 2017), highlighting different responses for various trophic groups. However, species are often aggregated in lower trophic levels of the food web due to difficulties in taxonomic identification and in segregating the energetics of smaller individuals (Baird et al., 2009). This has typically been the case for meiofauna as they are described as a single compartment in most recent steady-state mass-balanced food web models, or at best are split into nematodes and benthic copepods (Baird et al., 2007; Leguerrier et al., 2007, 2003; Pacella et al., 2013). Model input data (i.e. constraints) for meiofauna trophic groups are indeed scarce (Baird et al., 2009) and often derived from experimental studies on single specimens (Herman and Vranken, 1988; Vranken and Heip, 1986). Therefore, separating meiofauna into major trophic groups is necessary if a better understanding of their relationships with specific food sources and the role of these organisms in food webs is wanted. Trophic marker based approaches (e.g. stable isotopes), however, has shown successful to better constrain consumption flows of meiofauna trophic groups in food web models (Pacella et al., 2013; van Oevelen et al., 2010).

Using food web models, the general aim of this study was to determine how the roles of meiofauna and the food web efficiency can differ in coastal ecosystems depending on the composition of food sources (i.e. availability, quality and quantity). We focus on (1) the trophic relationship between meiofauna and their food sources, (2) production and transfer efficiency of meiofauna, and how these relate to those of macrofauna, and (3) the relationship between the food web efficiency and the composition of food sources. Finally, we provide recommendations on including meiofauna in future food web modeling studies. In this aim, five contrasting different intertidal habitats in terms of food sources and meiofauna group composition - providing several food web scenarios-were compared: habitats influenced by inputs of continental organic matter vs. habitats mostly influenced by marine inputs, habitats characterized by high loads of detrital matter vs. habitats with low loads of detrital matter, habitats with different communities of benthic microalgae. The food web models of these intertidal habitats of the Marennes-Oléron Bay and of the Sylt-Rømø Bight were compared using quantitative flow values and food web properties.

\section{Material and methods}

\subsection{Study sites and carbon flow networks}

Five benthic-pelagic coupled carbon flow networks were built, characterized by different food source compositions and different meiofauna communities. Model outputs from these five networks 
were compared to determine how the role of meiofauna differs depending on the composition of food sources. Both autochthonous and allochthonous food sources were considered. To consider autochthonous food sources, three types of habitats were studied: one characterized by high loads of detrital matter (i.e. seagrass bed), one characterized by a lower load of detrital matter and by a community of microphytobenthos dominated by epipelic diatoms (i.e. mudflat), and one characterized by a low load of detrital matter and by a community of microphytobenthos dominated by epipsammic diatoms (i.e. sandflat). To consider the role of allochthonous food sources, we studied the functioning of these habitats in two different ecosystems: one influenced by continental inputs of organic matter, i.e. the Marennes-Oléron Bay in France, into which the Charente river flows (Gouleau et al., 2000), and one with little direct continental inputs, hence influenced mainly by marine inputs, i.e. the Sylt-Rømø Bight in Germany (Asmus and Asmus, 2005, 1985). As sandflats are not a typical habitat in the Marennes-Oléron Bay, this habitat could not be considered in this ecosystem. As a result, seagrass beds and mudflats were studied in both the Marennes-Oléron Bay (MO) and the Sylt-Rømø Bight (SR), while the sandflat could only be studied in the Sylt-Rømø Bight, leading to five steady-state mass-balanced flow networks (i.e. one per habitat: mudflat MO, mudflat SR, seagrass MO, seagrass SR, and sandflat SR) (Fig. 1). These different habitats are characterized by different plant and animal communities that were previously described: seagrass MO (Lebreton, 2009; Lebreton et al., 2009), mudflat MO (Haubois et al., 2005; Rzeznik-Orignac et al., 2003), Sylt-Rømø Bight habitats (Asmus and Asmus, 2000, 2005, 1998, 1993; Asmus and Bauerfeind, 1994; Gätje and Reise, 1998), and additional information can be found in van der Heijden et al. (2018).

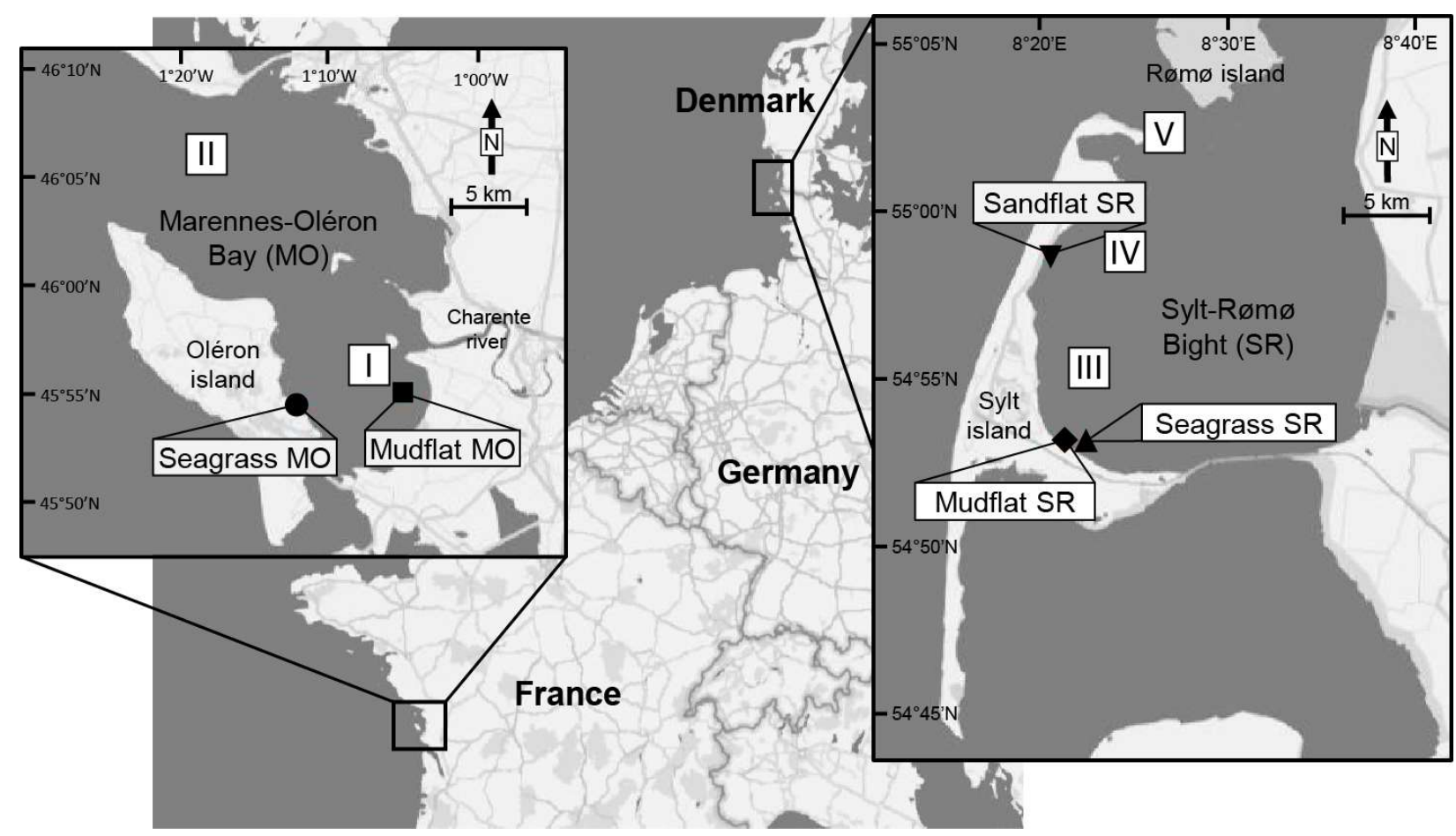

Figure 1. Study sites in the mudflats, seagrass beds and sandflat in the Marennes-Oléron Bay (MO) and the SyltRømø Bight (SR) along the European Atlantic coast. Pelagic sampling stations, where samples for suspended 
particulate organic matter were taken, are indicated with roman numbers in Marennes-Oléron Bay (I-II) and Sylt-Rømø Bight (III-V).

\subsection{Linear inverse model construction}

Linear inverse ecosystem models with Markov chain Monte Carlo (LIM-MCMC) were built to determine carbon flows in the five habitats on a daily basis $\left(\mathrm{mgC} \mathrm{m}^{-2} \mathrm{~d}^{-1}\right)$ using the $\mathrm{R}$ software ( $\mathrm{R}$ Core Team, 2019). The flow estimations originated from annual averages but are expressed as daily averages here. Annual averages were chosen in order to smoothen the daily and seasonal fluctuations that occur in these habitats, which can affect the network indices and prevent a clear comparison (Baird et al., 2004b; Baird and Ulanowicz, 1989). Most constraints, except for meiofauna constraints, that were used to construct the flow networks of these habitats originated from established models (Baird et al., 2007; Leguerrier et al., 2003; Pacella et al., 2013; Saint-Béat et al., 2014, 2013). New models focused on meiofauna and thus represented the diversity of this group at a higher resolution. Consequently, meiofauna was partitioned into five compartments according to their trophic group: selective deposit feeding nematodes, non-selective deposit feeding nematodes, epigrowth feeding nematodes, omnivorous/predating nematodes and benthic copepods. Recent in situ data on biomass (Table 1; van der Heijden et al., 2018) and on diets (used in stable isotope mixing models; van der Heijden et al., 2019) were used to constrain food web models. The prior established models aggregated meiofauna into two compartments, allowing us to compare the effects of this two-compartment partitioning versus the trophic group partitioning presented here. Macrofauna were aggregated based on feeding types (i.e. benthic deposit feeders, benthic grazers, suspension feeders and benthic omnivores/predators) in order to have a homogeneous topology of food web models (i.e. number of compartments), required when comparing different systems (Table 1; Baird and Ulanowicz, 1993).

Table 1. Abbreviations (Abbr.) and biomass of compartments used in the food web models of the mudflats, seagrass beds and sandflat in the Marennes-Oléron Bay (MO) and the Sylt-Rømø Bight (SR). NA = no data available; - = compartment absent.

\begin{tabular}{|c|c|c|c|c|c|c|}
\hline & & $\begin{array}{c}\text { Mudflat } \\
\text { Mo }\end{array}$ & $\begin{array}{c}\text { Seagrass } \\
\text { MO }\end{array}$ & $\begin{array}{c}\text { Sandflat } \\
\text { SR }\end{array}$ & $\begin{array}{c}\text { Mudflat } \\
\text { SR }\end{array}$ & $\begin{array}{c}\text { Seagrass } \\
\text { SR }\end{array}$ \\
\hline Number of compartments & & 19 & 21 & 17 & 17 & 20 \\
\hline Number of flows & & 123 & 138 & 100 & 96 & 108 \\
\hline Compartment & Abbr. & \multicolumn{5}{|c|}{ Biomass ( $\mathrm{mg} \mathrm{C} \mathrm{m}^{-2}$ ) } \\
\hline Terrestrial & & & & & & \\
\hline Carnivorous birds & $\mathrm{CBR}$ & 7.0 & 6.0 & 121.3 & 174.7 & 417.3 \\
\hline Herbivorous birds & HBR & - & 1.0 & - & - & 71.7 \\
\hline \multicolumn{7}{|l|}{ Benthic } \\
\hline Microphytobenthos & MPB & 3125.0 & 9250.0 & 130.0 & 120.0 & 120.0 \\
\hline Zostera noltii (seagrass tissues) & ZOS & - & 6133.3 & - & - & 30890.0 \\
\hline Benthic bacteria & BBA & 947.0 & 947.0 & 625.0 & 625.0 & 625.0 \\
\hline Nematodes - selective deposit feeders & NBA & 70.5 & 4.6 & 0.3 & 5.5 & 2.0 \\
\hline Nematodes - non-selective deposit feeders & NDF & 496.9 & 60.8 & 40.3 & 58.2 & 58.2 \\
\hline
\end{tabular}




\begin{tabular}{|c|c|c|c|c|c|c|}
\hline Nematodes - epigrowth feeders & $\mathrm{NEF}$ & 607.5 & 165.5 & 23.2 & 19.4 & 279.4 \\
\hline Nematodes - omnivores/predators & NOM & 82.5 & 63.2 & 60.2 & 19.1 & 11.0 \\
\hline Benthic copepods & $\mathrm{COP}$ & 94.8 & 78.3 & 50.1 & 6.0 & 6.1 \\
\hline Macrofauna - benthic deposit feeders & BDF & 3.5 & 98.8 & 6797.6 & 3997.6 & 12841.2 \\
\hline Macrofauna - benthic grazers & BGR & 695.6 & 4076.6 & 406.0 & 8004.0 & 7174.6 \\
\hline Macrofauna - benthic suspension feeders & SUS & 42.7 & 1704.8 & 19204.6 & 6275.6 & 12048.1 \\
\hline Macrofauna - benthic omnivores/carnivores & $\mathrm{BOM}$ & 597.4 & 50.8 & 729.6 & 2939.8 & 1097.9 \\
\hline Sediment organic matter & $\mathrm{SOM}$ & NA & 27560.0 & 19000.0 & 19000.0 & 19000.0 \\
\hline \multicolumn{7}{|l|}{ Pelagic } \\
\hline Phytoplankton & PHY & 254.5 & 254.5 & 1040.0 & 1040.0 & 1040.0 \\
\hline Pelagic bacteria & PBA & 157.2 & 157.2 & 9.0 & 9.0 & 9.0 \\
\hline Mesozooplankton & $\mathrm{ZOO}$ & 160.0 & 160.0 & 11.2 & - & - \\
\hline Microzooplankton & $\mathrm{MZO}$ & 110.0 & - & - & - & - \\
\hline Benthic fish & BFI & 195.0 & 195.0 & 2.9 & 1.5 & 14.9 \\
\hline Suspended particulate organic matter & SPOM & NA & 1044.2 & 500.0 & 500.0 & 500.0 \\
\hline Dissolved organic matter & DOC & - & 1850.3 & - & - & 62.0 \\
\hline
\end{tabular}

\subsubsection{Established model constraints}

219

The model of mudflat MO was based on data provided by Leguerrier et al. (2003), Degré et al. (2006), Saint-Béat et al. (2014) (Appendices A.1 and A.2). Original compartments of this previous model were used as a basis for the other food web models and therefore no aggregations were conducted.

The seagrass MO model was based on data provided by Pacella et al. (2013) (Appendix A.3). Biomass of bacteria for the whole Marennes-Oléron Bay was obtained from Leguerrier et al. (2003). Macrofauna constraints used in Pacella et al. (2013) were aggregated based on feeding types. Trophic groups were: benthic deposit feeders (Abra spp., Arenicola marina, and Notomastus latericeus), benthic grazers (Peringia ulvae and gastropod grazers), benthic omnivores/predators (Carcinus maenas, Crangon crangon, and Cerebratulus marginatus), and suspension feeders (Cerastoderma edule, Limecola balthica, Mytilus galloprovincialis, Scrobicularia plana, and Tapes spp.). Consumption rates of these feeding groups were estimated using aggregated stable isotope values (Pacella et al., 2013). Aggregation was done based on weighted averages using biomass and flows of the different genera.

The models of habitats from the Sylt-Rømø Bight (i.e. mudflat SR, seagrass SR and sandflat SR) were based on data provided by Baird et al. (2007) and modified by Saint-Béat et al. (2013) (Appendices A.4 to A.6). For these models fewer minimum and maximum values of flow constraints (mainly production and consumption constraints) were known compared to models of the Marennes-Oléron Bay. Equalities, provided by Saint-Béat et al. (2013), were therefore converted to inequalities by increasing or reducing the equality value with $30 \%$. These ranges correspond with seasonal fluctuations observed for macrofauna by Asmus (1987) and were considered to be the most appropriate estimations based on sensitivity analyses from Guesnet et al. (2015). 


\subsubsection{Complementary constraints: outputs of isotope mixing models}

Meiofauna compartments from previous models were partitioned into benthic copepods and trophic groups of nematodes (i.e. selective deposit feeders, non-selective deposit feeders, epigrowth feeders and omnivores/predators) and constraints were calculated for these new compartments based on stable isotope data. Stable isotope mixing models MixSIAR (Stock et al., 2018) were applied to isotope data from van der Heijden et al. (2019) to compute the dietary contribution of food sources to benthic copepods and trophic groups of nematodes in all habitats. We used the $\delta^{13} \mathrm{C}$ and $\delta^{15} \mathrm{~N}$ values (mean and standard deviation) of the food sources (i.e. suspended particulate organic matter (SPOM), sediment organic matter (SOM) and microphytobenthos from van der Heijden et al. (2019), those of sulfide-oxidizing bacteria from Vafeiadou et al. (2014)) and meiofauna consumers (i.e. benthic copepods and trophic groups of nematodes). Complementary information about parametrization of mixing models can be found in van der Heijden et al. (2019). The 90\% credibility intervals (CI) provided by the mixing models are reported here and were used as constraints (lower and upper limits) in the food web models, following the approach of Pacella et al. (2013).

\subsection{Calculation of LIM solutions}

Mass balance of each compartment and constraints were integrated into the LIM-MCMC models. Matrices of the linear equations ( $A$ and $G$ ) were combined with the vectors of equalities (b) and inequalities (h) to generate the vector of unknown flows (x) (van den Meersche et al., 2009):

$$
\begin{array}{ll}
\text { Equality equation: } & \mathrm{A} * \mathrm{x}=\mathrm{b} \\
\text { Inequality equation: } & \mathrm{G} * \mathrm{x} \geq \mathrm{h}
\end{array}
$$

The vectors $\mathrm{x}$ were then estimated by sampling through a solution space using the LIM-MCMC mirror defined by (van den Meersche et al., 2009) and revised by (van Oevelen et al., 2010). A range of possible values for each vector $\mathrm{x}$ (flow) was determined based on 500,000 solutions (jump size of 0.5). Model simulations were realized using the limSolve package (Soetaert et al., 2017) from van Oevelen et al. (2010). Visual observations of iterated flow values provided information on the stability of the iterations and the completeness of the sampled solution space, and thereby validated the total number of iterations and jumps selected.

\subsection{Computation of indices and ratios}

Indices and ratios were calculated from the LIM-MCMC estimated solutions and via network analyses in the purpose of (1) determining how flows of organic matter change between food sources and meiofauna trophic groups depending on food source availability and (2) determine how meiofauna 
mediate the transfer of carbon to higher trophic levels depending on food web characteristics (e.g. availability of food sources, structures of meiofauna and macrofauna communities). For both questions, several indices were computed and compared to provide a comprehensive interpretation of the food web functioning, and to compare roles of meiofauna and macrofauna.

\subsubsection{Food web indices and ratios}

Flows of carbon, omnivory indices and dependency ratios were calculated to determine and analyze trophic relationships between food sources and consumers. Flows of carbon $\left(\mathrm{mg} \mathrm{C} \mathrm{m}^{-2} \mathrm{~d}^{-1}\right)$ express trophic relationships between food sources and consumers. Omnivory index (formula in Appendix B.1) is a ratio expressing the variability of food sources consumed by a consumer (e.g. a trophic group of meiofauna), highlighting its degree of omnivory. Dependency ratio determines the dependence of a consumer on a food source through both direct and indirect pathways, providing information about the origin of carbon assimilated by each compartment. Because an atom of carbon can go through several compartments before it is consumed by a particular organism, the sum of dependency ratios can exceed the value of 1.0 (Baird and Ulanowicz, 1989).

Production rates, production/biomass ratios and transfer efficiency were computed to determine significance of meiofauna in the carbon transfer through each distinct food web. Production rates were calculated using the export, consumption, egestion and respiration (Production $=$ consumption egestion - respiration - export). Production/biomass ratio, an estimation of the activity per biomass unit, was used to determine the activity of a compartment in the habitat. The transfer efficiency was calculated based on inputs, losses due to respiration, exports and outputs as detritus and transfers to higher trophic levels. It highlights the efficiency of the energy transfered from one trophic level to the next (Baird et al., 2004a). Mean transfer efficiency (MTE) was calculated as the geometric mean of transfer efficiencies for trophic level II to IV (Heymans et al., 2014).

Transfer efficiencies originated from Lindeman spines which illustrate food webs as linear food chains with integer trophic levels (Lindeman, 1942; Wulff et al., 1989), for which the inputs, losses due to respiration, exports and output as detritus and transfers to higher trophic levels are detailed. Modified Lindeman spines were used to extract the information for meiofauna. Meiofauna consumers were distributed in their respective trophic levels according to their feeding behavior.

\subsubsection{Network analysis indices}

Four ecosystem network analysis (ENA) indices were computed: Total system throughput (TSTp), Finn cycling index (FCI), internal ascendency $\left(\mathrm{A}_{\mathrm{i}}\right)$ and average path length (APL) (formulas in Appendix B.1). These ENA indices provide information about the efficiency of the food webs. TSTp reflects the sum of all network flows within the system (Latham, 2006), and is also considered as the 
total power generated within the system (Baird et al., 1998). Note the difference between the TSTp and the total system through-flow (TSTf), used by Leguerrier et al. (2003). TSTf, which is the sum of compartmental through-flow (Latham, 2006), is reported here as well to facilitate comparisons. FCI estimates the proportion of organic carbon that flows through loops (i.e. cycles) (Baird et al., 2004b, 2004a; Baird and Ulanowicz, 1989; Finn, 1976). Internal ascendency $\left(A_{i}\right)$ measures the efficiency and definitiveness by which energy is transferred within a food web. Higher $A_{i}$ highlights increased ecological succession (Baird et al., 2007; Scharler and Baird, 2005). Average path length (APL) defines the average number of compartments through which a unit of energy (i.e. carbon) passes between entering and leaving the food web (Christensen, 1995). This parameter is expected to be higher in food webs with higher flow diversity and cycling (Christensen, 1995; Thomas and Christian, 2001). The indices were calculated from 500,000 estimated flow solutions using the enaR package (Lau et al., 2017).

\subsection{Statistical methods}

In order to test the pairwise difference of index values between the habitats, Cliff's delta statistic method (Cliff, 1993; Macbeth et al., 2010) from the effsize package (Torchiano, 2019) was used, following Tecchio et al. (2016). This method uses a non-parametric effect size statistic to estimate the probability that a randomly selected value in the first sample is higher than a randomly selected value in the second sample, minus the reverse probability. Whether the difference is due to an effective ecological meaning or sample size alone can be tested by comparing the degree of overlap between the two distributions. Threshold values were used to determine the degree of significance (Romano et al., 2006) with low threshold values indicating a similarity between index values (negligible: $|\delta|<0.147$ and small $|\delta|<0.33$ ) and higher delta values indicating a significant difference between values of both indices (medium $|\delta|<0.474$ and large $|\delta|>0.474$ ).

\section{Results}

\subsection{General characteristics of the food web models}

The food web models of the five habitats from the two ecosystems, the Marennes-Oléron Bay and the Sylt-Rømø Bight, integrated different compartments with varying biomass (Table 1), energy requirements and production estimates which resulted in distinctly different trophic interactions (Fig. 2-4, flow values in Appendix B.2). For meiofauna compartments, constraints that were used to generate flow networks were based on outputs of stable isotope mixing models (Appendix B.3). The carbon flow networks of the five habitats were cast into a simplified construction of each food web (Fig. 2-4) which excludes respiration, import, export and flow to detritus. 
Higher biomass of microphytobenthos, benthic bacteria, pelagic bacteria, zooplankton and

345 benthic fish were observed in the habitats of the Marennes-Oléron Bay, whereas biomass of seagrass,

346 phytoplankton, benthic deposit feeders, suspension feeders and carnivorous birds were higher in the

347 habitats of the Sylt-Rømø Bight (Table 1). The different habitats in the Sylt-Rømø Bight were generally

348 more similar in terms of compartment biomass compared to the habitats of the Marennes-Oléron Bay.

349 Biomass of meiofauna compartments varied as well between habitats. The dominant trophic groups of 350 meiofauna were non-selective deposit feeders in mudflat SR, epigrowth feeders in seagrass MO and 351 seagrass SR, both non-selective deposit feeders and epigrowth feeders in mudflat MO, and non352 selective deposit feeders, omnivores/predators and benthic copepods in sandflat SR. Selective deposit 353 feeders had low relative biomass in the mudflats (5\%) and seagrass beds (1\%) and were nearly absent 354 in the sandflat of the Sylt-Rømø Bight. Bay habitats $(60.6 \%$, Fig. 2), due to the higher biomass of meiofauna in the mudflat MO $357\left(1352.1 \mathrm{mgC} \mathrm{m}^{-2}\right)$. Moderate proportions of carbon flowed through meiofauna in the seagrass MO 358 (29.6\%, Fig. 2), seagrass SR (32.2\%, Fig. 3) and mudflat SR (23.8\%, Fig. 3), whereas low proportions of carbon passed through meiofauna in the sandflat SR (9.9\%, Fig. 4). Larger proportions of carbon 360 flowed through macrofauna compartments (64.5-69.8\%, Fig. 3 and 4) in the Sylt-Rømø Bight habitats, 361 where biomass of meiofauna were between 100-fold (seagrass SR) and 200-fold (mudflat SR) lower 362 compared to macrofauna biomass. In the mudflat MO, where meiofauna and macrofauna biomass were 363 similar, the carbon distribution is skewed in favor of meiofauna (Fig. 2). In the seagrass MO moderate 364 proportions of carbon flowed through macrofauna (17.8\%, Fig. 2) even though its biomass was 15 times 365 higher than meiofauna. 


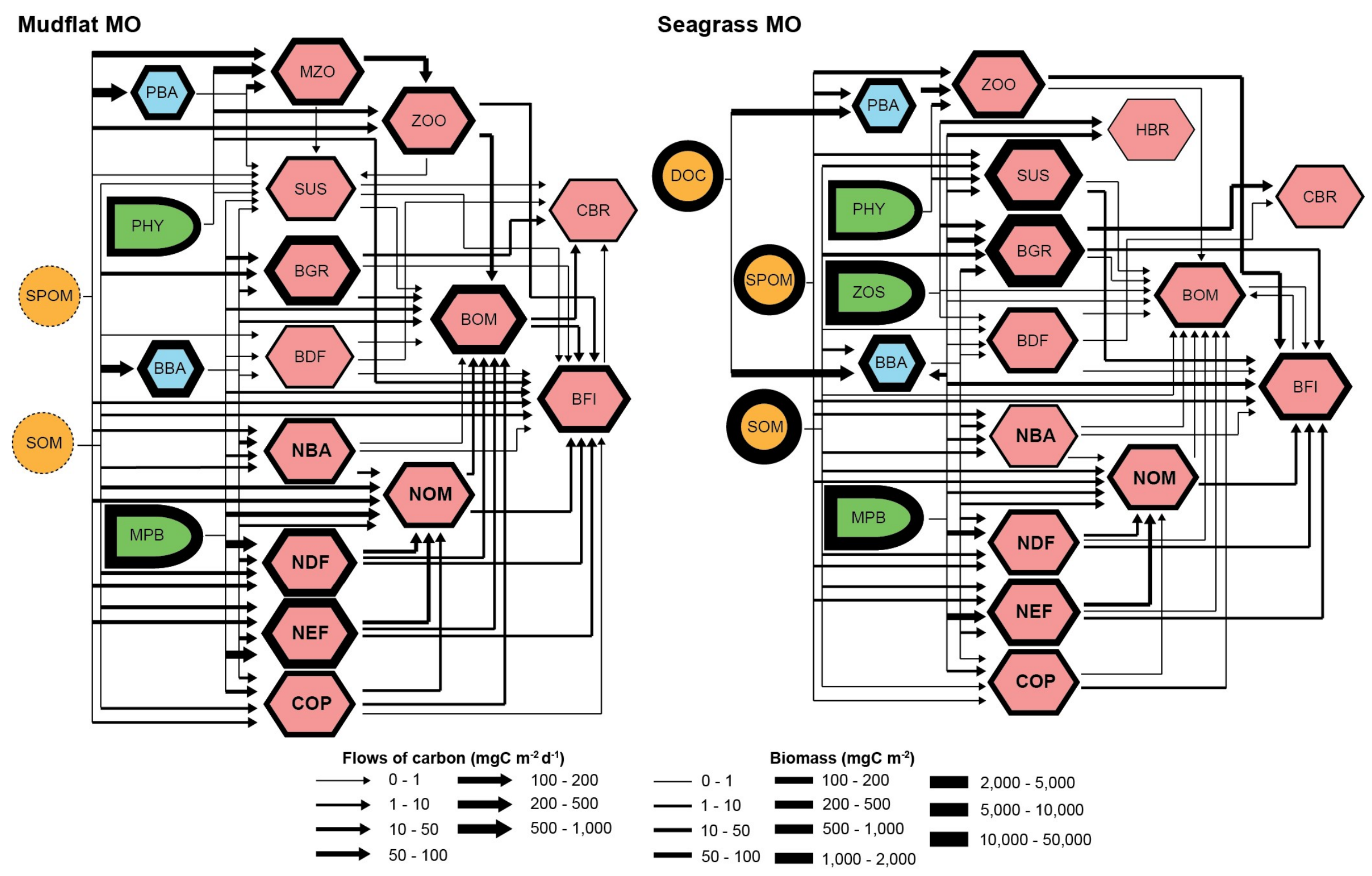


Figure 2. Food webs of the mudflat and seagrass bed in the Marennes-Oléron Bay (MO) obtained by linear inverse modeling. The mudflat MO food web model consists of two primary producer compartments (green), two bacteria compartments (blue), two detrital compartments (orange) and 13 consumer compartments (pink). The seagrass MO food web model consists of three primary producer compartments (green), two bacteria compartments (blue), three detrital compartments (orange) and 13 consumer compartments (pink). Arrow thickness indicates the magnitude of the flow between compartments, with exact flow values given in Appendix B.2, and compartment thickness indicates the magnitude of the biomass, with exact biomass given in Table 1. Biomass of SOM and SPOM in mudflat MO are unknown (stippled boxes). Meiofauna compartments are in bold letters. $\mathrm{BBA}=$ benthic bacteria, $\mathrm{BDF}=$ benthic deposit feeding macrofauna, $\mathrm{BFI}=$ benthic fish, $\mathrm{BGR}=$ benthic grazing macrofauna, $\mathrm{BOM}=$ benthic omnivorous macrofauna, $\mathrm{COP}=$ benthic copepods, $\mathrm{CBR}=$ carnivorous birds, $\mathrm{DOC}=$ dissolved organic carbon, $\mathrm{HBR}=$ herbivorous birds, $\mathrm{MPB}=$ microphytobenthos, $\mathrm{MZO}=$ microzooplankton, $\mathrm{NBA}=$ selective deposit feeding nematodes, $\mathrm{NDF}=$ non-selective deposit feeding nematodes, $\mathrm{NEF}=$ epigrowth feeding nematodes, $\mathrm{NOM}=$ omnivorous/predating nematodes, $\mathrm{PBA}=$ pelagic bacteria, $\mathrm{PHY}=$ phytoplankton, $\mathrm{SPOM}=$ suspended particulate organic matter, $\mathrm{SOM}=$ sediment organic matter, $\mathrm{SUS}=$ 376 suspension feeding macrofauna, $\mathrm{ZOO}=$ mesozooplankton, $\mathrm{ZOS}=$ Zostera noltii material. 


\section{Mudflat SR}

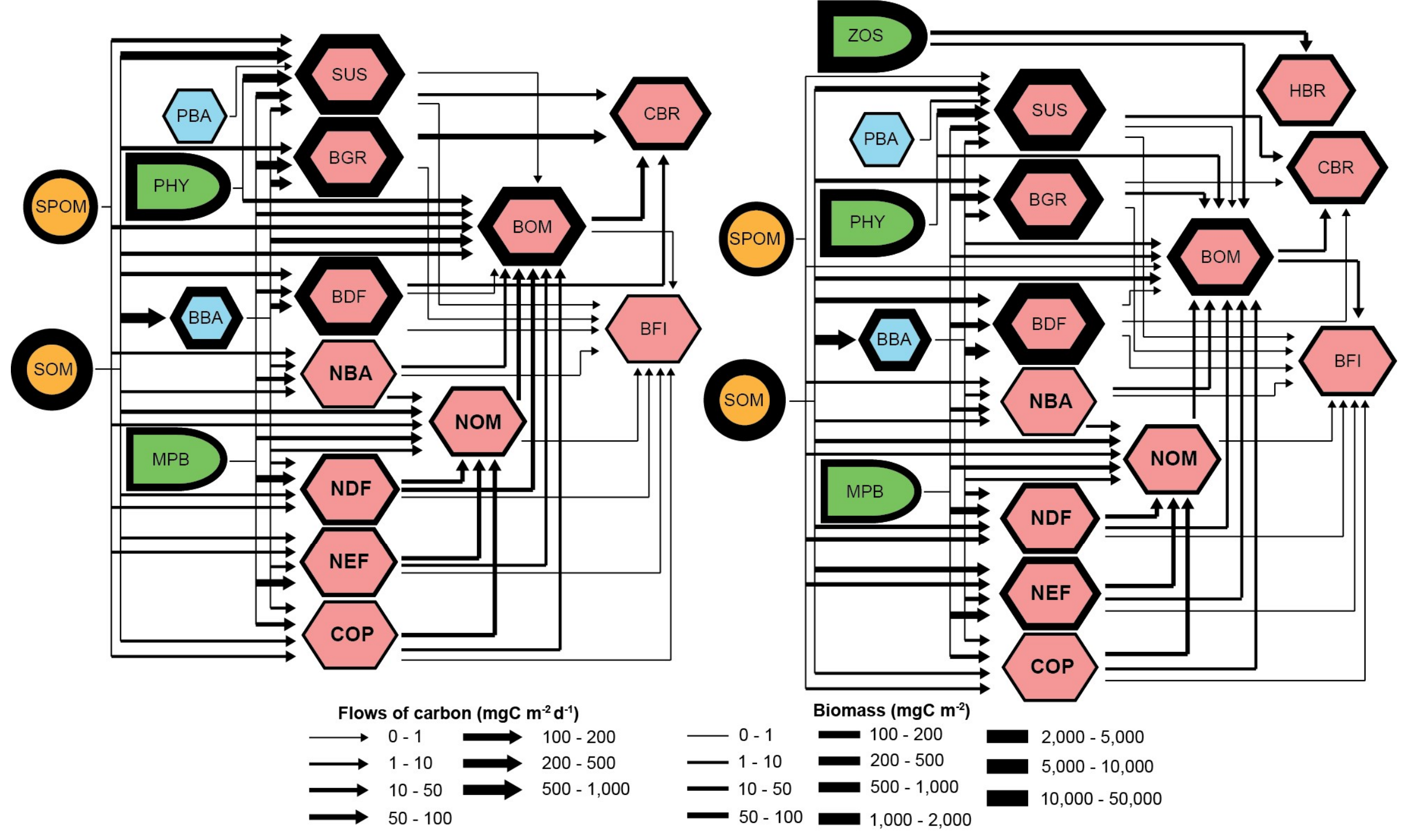


Figure 3. Food webs of the mudflat and seagrass bed in the Sylt-Rømø Bight (SR) obtained by linear inverse modeling. The mudflat SR food web model consists of two primary producer compartments (green), two bacteria compartments (blue), two detrital compartments (orange) and 11 consumer compartments (pink). The seagrass SR food web model consists of three primary producer compartments (green), two bacteria compartments (blue), two detrital compartments (orange) and 12 consumer compartments (pink). Arrow thickness indicates the magnitude of the flow between compartments, with exact flow values in Appendix B.2, and compartment thickness indicates the magnitude of the biomass, with exact biomass given in Table 1. Meiofauna compartments are in bold. BBA =benthic bacteria, BDF = benthic deposit feeding macrofauna, $\mathrm{BFI}=$ benthic fish, $\mathrm{BGR}=$ benthic grazing macrofauna, $\mathrm{BOM}=$ benthic omnivorous macrofauna, $\mathrm{COP}=$ benthic copepods, $\mathrm{CBR}=$ carnivorous birds, $\mathrm{HBR}=$ herbivorous birds, $\mathrm{MPB}=$ microphytobenthos, $\mathrm{NBA}=$ selective deposit feeding nematodes, $\mathrm{NDF}=$ non-selective deposit feeding nematodes, $\mathrm{NEF}=$ epigrowth feeding nematodes, $\mathrm{NOM}=$ omnivorous/predating nematodes, $\mathrm{PBA}=$ pelagic bacteria, $\mathrm{PHY}=$ phytoplankton, $\mathrm{SPOM}=$ suspended particulate organic matter, $\mathrm{SOM}=$ sediment organic matter, $\mathrm{SUS}=$ suspension feeding macrofauna, $\mathrm{ZOS}=$ Zostera noltii material.

\section{Sandflat SR}

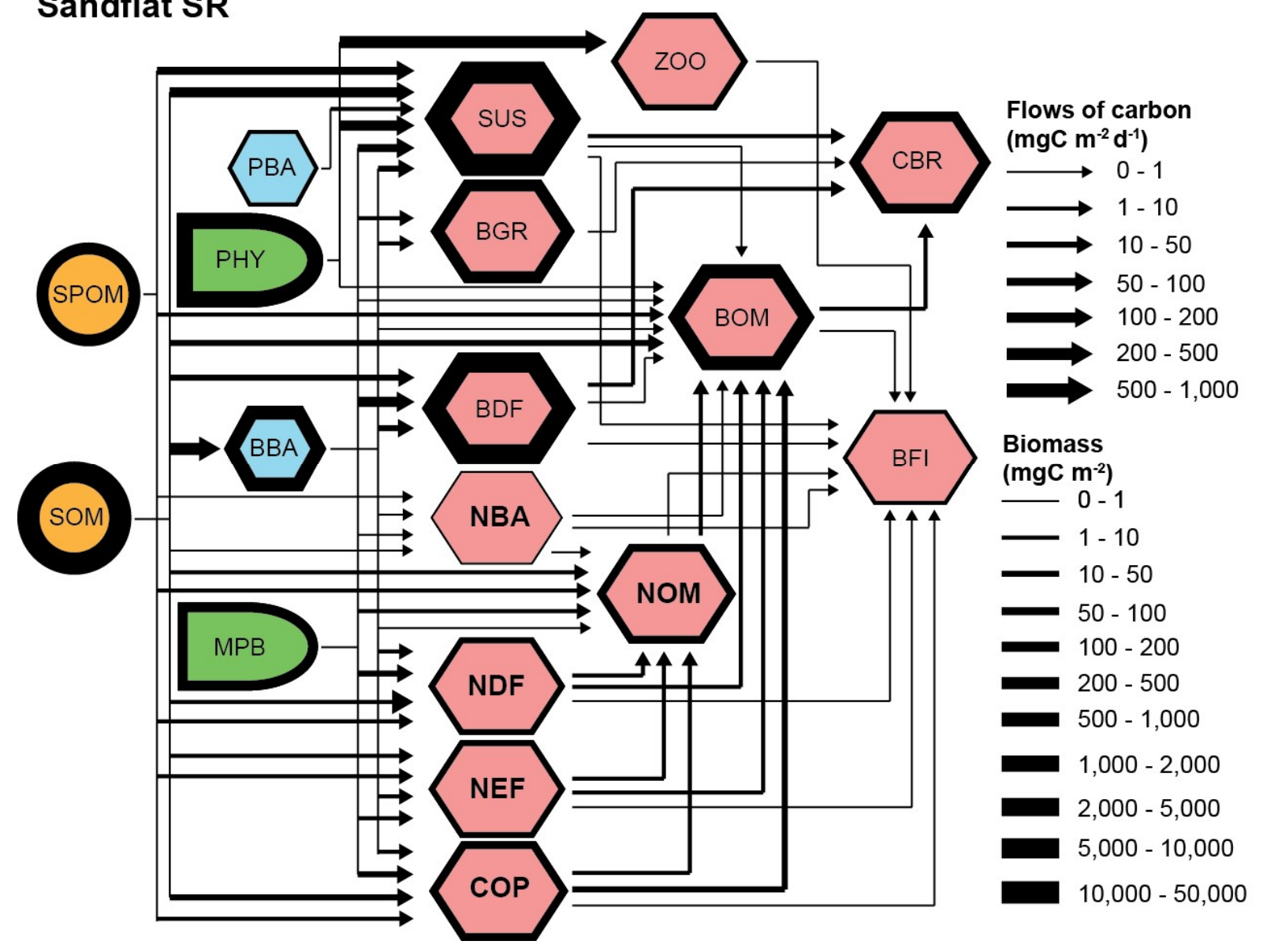

Figure 4. Food web of the sandflat in the Sylt-Rømø Bight (SR) obtained by linear inverse modeling. This model consists of two primary producer compartments (green), two bacteria compartments (blue), two detrital compartments (orange) and 12 consumer compartments (pink). Arrow thickness indicates the magnitude of the flow between compartments, with exact flow values in Appendix B.2, and compartment thickness indicates the magnitude of the biomass, with exact biomass given in Table 1. Meiofauna compartments are in bold. $\mathrm{BBA}=$ benthic bacteria, $\mathrm{BDF}=$ benthic deposit feeding macrofauna, $\mathrm{BFI}=$ benthic fish, $\mathrm{BGR}=$ benthic grazing macrofauna, $\mathrm{BOM}=$ benthic omnivorous macrofauna, $\mathrm{COP}=$ benthic copepods, $\mathrm{CBR}=$ carnivorous birds, $\mathrm{MPB}=$ microphytobenthos, $\mathrm{MZO}=$ microzooplankton, $\mathrm{NBA}=$ selective 
deposit feeding nematodes, NDF = non-selective deposit feeding nematodes, NEF = epigrowth feeding nematodes, NOM $=$ omnivorous/predating nematodes, $\mathrm{PBA}=$ pelagic bacteria, $\mathrm{PHY}=$ phytoplankton, $\mathrm{SPOM}=$ suspended particulate organic matter, $\mathrm{SOM}=$ sediment organic matter, $\mathrm{SUS}=$ suspension feeding macrofauna, $\mathrm{ZOO}=$ mesozooplankton .

\subsection{Flows from food sources to meiofauna and macrofauna}

\subsubsection{Meiofauna and macrofauna feeding behavior}

Meiofauna and macrofauna had different feeding behaviors as meiofauna relied merely on a single food source: microphytobenthos (60 to $81 \%$ of total consumption); with flows of microphytobenthos to meiofauna ranging from 62.8 (sandflat SR) to $674.9 \mathrm{mgC} \mathrm{m}^{-2} \mathrm{~d}^{-1}$ (mudflat MO) (Fig. 5). Meiofauna secondary food sources were the SOM (from 17.1 to $102.2 \mathrm{mgC} \mathrm{m}^{-2} \mathrm{~d}^{-1}$ ) and bacteria (from 7.2 to $92.3 \mathrm{mgC} \mathrm{m}^{-2} \mathrm{~d}^{-1}$ ), when pelagic food sources (i.e. SPOM and phytoplankton) were poorly used by meiofauna. Macrofauna, on the other hand, relied on a larger diversity of resources but microphytobenthos was their major food source in three of the five habitats (mudflat SR, seagrass MO and seagrass SR), with flows ranging from 91.6 (seagrass $\mathrm{MO}$ ) to $398.2 \mathrm{mgC} \mathrm{m}^{-2} \mathrm{~d}^{-1}$ (mudflat SR). Consumption of bacteria, phytoplankton and SOM by macrofauna was much higher in habitats of the Sylt-Rømø Bight (bacteria: from 144.5 to $288.3 \mathrm{mgC} \mathrm{m}^{-2} \mathrm{~d}^{-1}$, phytoplankton: from 171.9 to $246.1 \mathrm{mgC} \mathrm{m}^{-2} \mathrm{~d}^{-1}$, SOM: from 165.3 to $372.5 \mathrm{mgC} \mathrm{m}^{-2} \mathrm{~d}^{-1}$ ) than in the Marennes-Oléron Bay (bacteria: from 4.5 to $16.8 \mathrm{mgC} \mathrm{m}^{-2} \mathrm{~d}^{-1}$, phytoplankton: from $<0.1$ to $2.8 \mathrm{mgC} \mathrm{m}^{-2} \mathrm{~d}^{-1}$, SOM: from 22.8 to 33.3 $\mathrm{mgC} \mathrm{m} \mathrm{d}^{-1}$ ). Seagrass material were used very little by meiofauna and macrofauna.

Comparisons of flows between macrofauna and meiofauna highlighted the large differences between habitats. In the Marennes-Oléron Bay habitats, flows from microphytobenthos to benthic primary consumers were higher than the sum of all the other ones. In these habitats, carbon flows of microphytobenthos accounted indeed for about $70 \%$ of the total sum of flows, whereas SOM and bacteria only accounted for $11 \%$ and $10 \%$ of the total carbon flows towards benthic consumers, respectively. In the Sylt-Rømø Bight habitats, total carbon flows towards benthic consumers were originating from more diverse sources such as microphytobenthos (21-43\%), SOM (20-25\%), phytoplankton (13-23\%), bacteria (10-21\%) and SPOM (3$10 \%)$. At the scale of consumers, flows towards macrofauna were much higher in the Sylt-Rømø Bight habitats compared to those of the Marennes-Oléron Bay where meiofauna dominated grazing. 


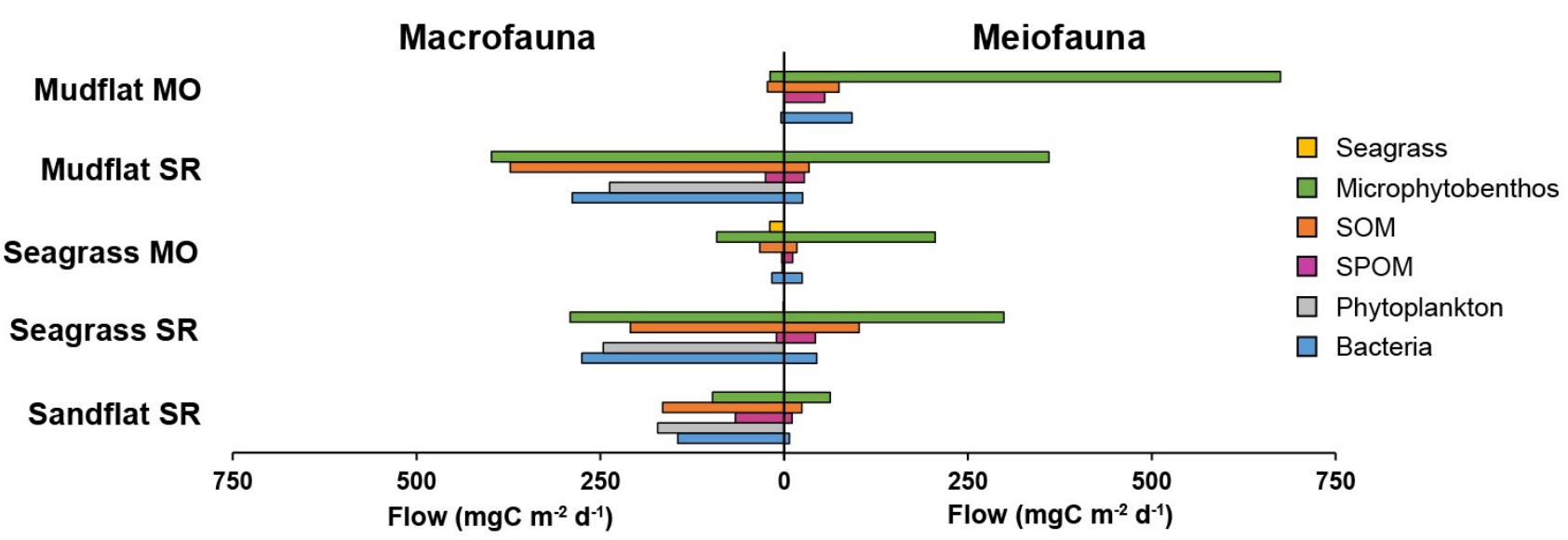

432

Figure 5. Flows of carbon from food sources to meiofauna and macrofauna in the mudflats, seagrass beds, and sandflat in the Marennes-Oléron Bay (MO) and the Sylt-Rømø Bight (SR). SOM = sediment organic matter, SPOM= suspended particulate organic matter.

\subsubsection{Flows from food sources to meiofauna trophic groups}

Within the meiofauna, three main feeding strategies were observed among the different trophic groups. First, meiofauna from three trophic groups: non-selective deposit feeding nematodes, epigrowth feeding nematodes and benthic copepods, mostly relying on microphytobenthos with flows from 15.4-303.2 $\mathrm{mgC} \mathrm{m} \mathrm{d}^{-1}$, from 9.9-280.8 $\mathrm{mgC} \mathrm{m}^{-2} \mathrm{~d}^{-1}$ and from 1.8-29.3 $\mathrm{mgC} \mathrm{m}^{-2} \mathrm{~d}^{-1}$, respectively (Fig. 6, Appendix B.4). The high reliance of these consumers on microphytobenthos in all habitats was demonstrated by the dependency ratios, ranging from 0.73 to 0.97 (Fig. 6), and their very low omnivory indices $(0.03-0.10$; Table 2). Habitat comparisons highlighted that non-selective deposit feeders and epigrowth feeders had much higher inputs of microphytobenthos in the mudflats and seagrass beds than in the sandflat SR. Lastly, benthic copepods had a lower relative carbon input from microphytobenthos in seagrass MO than in other habitats.

Second, selective deposit feeding nematodes relied on more variable food sources (Fig. 6, Appendix B.4). They relied mostly on bacteria in the Marennes-Oléron Bay habitats $\left(8.2-35.9 \mathrm{mgC} \mathrm{m}^{-2} \mathrm{~d}^{-1}\right)$, whereas they mostly used microphytobenthos in the Sylt-Rømø Bight habitats $\left(0.5-16.1 \mathrm{mgC} \mathrm{m}^{-2} \mathrm{~d}^{-1}\right)$. In all habitats except seagrass MO, dependency ratios of selective deposit feeders highlighted that they rely on a large diversity of food sources: microphytobenthos, SOM and bacteria (Fig. 6). In the Marennes-Oléron seagrass bed, the contribution of microphytobenthos and bacteria to the carbon requirements of selective deposit feeders were similar as confirmed by their dependency ratio in this habitat (Fig. 6).

Third, omnivorous/predating nematodes relied on microphytobenthos (7.8-61.2 $\left.\mathrm{mgC} \mathrm{m}^{2} \mathrm{~d}^{-1}\right)$ as well as on other meiofauna (10.3-83.6 $\mathrm{mgC} \mathrm{m}^{-2} \mathrm{~d}^{-1}$ ) (Fig. 6, Appendix B.4), as also demonstrated by their relatively higher omnivory index (0.26 to 0.30 , Table 2$)$. Still, dependency ratios demonstrated that omnivores/predators depended mostly on carbon of microphytobenthos origin in all habitats with ratios ranging from 0.75 (seagrass SR) to 0.94 (mudflat MO) (Fig. 6). 
459 Table 2. Omnivory indices for trophic groups of nematodes and benthic copepods in the mudflats, seagrass beds, and 460 sandflat in the Marennes-Oléron Bay (MO) and the Sylt-Rømø Bight (SR).

\begin{tabular}{lccccc}
\hline & Omnivory index & & & \\
\hline & Mudflat MO & Mudflat SR & Seagrass MO & Seagrass SR & Sandflat SR \\
\hline Nematodes - selective deposit feeders & 0.17 & 0.17 & 0.25 & 0.16 & 0.19 \\
Nematodes - non-selective deposit feeders & 0.05 & 0.03 & 0.08 & 0.07 & 0.05 \\
Nematodes - epigrowth feeders & 0.07 & 0.03 & 0.04 & 0.08 & 0.07 \\
Nematodes - omnivores/predators & 0.30 & 0.26 & 0.26 & 0.28 & 0.28 \\
Benthic copepods & 0.08 & 0.08 & 0.05 & 0.10 & 0.06 \\
\hline
\end{tabular}

461 

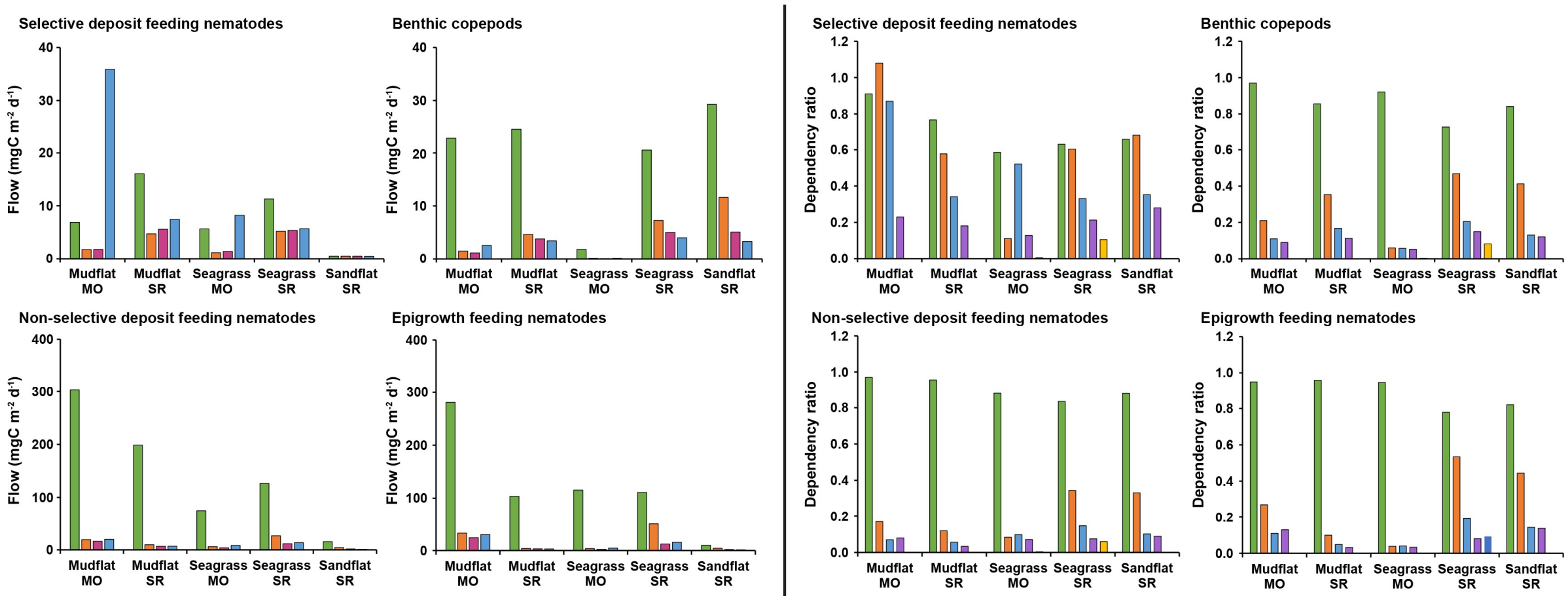

Omnivorous/predating nematodes

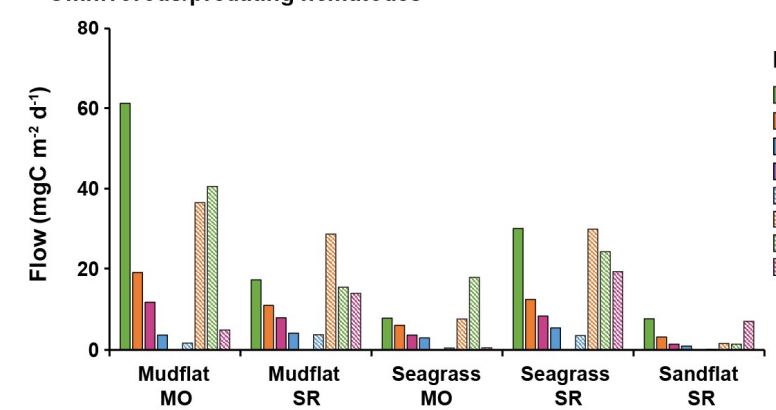

Food sources

Microphytobenthos

som

Bacteria

Selective deposit feeding nematodes

Epigrowth feeding nematodes

Benthic copepods

Figure 6. Flows of carbon $\left(\mathrm{mgC} \mathrm{m}^{-2} \mathrm{~d}^{-1}\right)$ from food sources to meiofauna trophic groups (left panel) and dependency ratios of meiofauna trophic groups on food sources (right panel) in the mudflats, seagrass beds, and sandflat in the Marennes-Oléron Bay (MO) and the Sylt-Rømø Bight (SR). Trophic groups: selective deposit feeding nematodes, non-selective deposit feeding nematodes, epigrowth feeding nematodes, omnivorous/predating nematodes and benthic copepods. Primary food sources: microphytobenthos, sediment organic matter (SOM), bacteria and suspended particulate organic matter (SPOM). Values are displayed in Appendix B.2 (flows of carbon) and Appendix B.5

467 (dependency ratios). 


\subsection{Production and transfer efficiency}

\subsubsection{Production of food sources}

Microphytobenthos was the most important primary producer in all habitats with the largest gross primary production (GPP) ranging from 774.4 (sandflat SR) to $1161.9 \mathrm{mgC} \mathrm{m}^{-2} \mathrm{~d}^{-1}$ (mudflat $\mathrm{MO}$ ), and microphytobenthos represented between $47.3 \%$ (seagrass SR) to $81.3 \%$ (seagrass MO) of the primary production (Table 3). The highest GPP of microphytobenthos was measured in the two mudflats, as well as in seagrass MO, while GPP was much lower in seagrass SR and sandflat SR. Other primary producers were also characterized by large difference of GPP between habitats (Table 3). GPP of seagrass was much lower than that of microphytobenthos in seagrass MO (45.1 compared to $\left.1043.1 \mathrm{mgC} \mathrm{m}^{-2} \mathrm{~d}^{-1}\right)$ and slightly lower than that of microphytobenthos in seagrass SR (685.3 compared to $\left.836.6 \mathrm{mgC} \mathrm{m}^{-2} \mathrm{~d}^{-1}\right)$. GPP of phytoplankton varied from 194.2 to $536.0 \mathrm{mgC} \mathrm{m}^{-2} \mathrm{~d}^{-1}$, with the highest production occurring in mudflat $\mathrm{MO}\left(536.0 \mathrm{mgC} \mathrm{m}^{-2} \mathrm{~d}^{-1}\right)$ and sandflat SR (446.5 $\mathrm{mgC} \mathrm{m} \mathrm{m}^{-2} \mathrm{~d}^{-1}$ ). Production of bacteria was more variable than production of microphytobenthos, with much higher values in the habitats of the Sylt-Rømø Bight (147.7 to 317.5 $\mathrm{mgC} \mathrm{m} \mathrm{d}^{-1}$ ) than in the habitats of the Marennes-Oléron Bay (41.3 to $96.8 \mathrm{mgC} \mathrm{m}^{-2} \mathrm{~d}^{-1}$, Table 3).

Table 3. Primary production of primary producers (with proportion of total primary production in italic; \%), secondary production of bacteria, meiofauna and macrofauna and production/biomass ratios of meiofauna and macrofauna in the mudflats, seagrass beds, and sandflat in the Marennes-Oléron Bay (MO) and the Sylt-Rømø Bight (SR). Secondary production of meiofauna and macrofauna are weighted averages of the combined compartments weighted by their biomass.

\begin{tabular}{|c|c|c|c|c|c|}
\hline & \multicolumn{5}{|c|}{ Primary production $\left(\mathrm{mgC} \mathrm{m}^{-2} \mathrm{~d}^{-1}\right)$} \\
\hline & Mudflat MO & Mudflat SR & Seagrass MO & Seagrass SR & Sandflat SR \\
\hline \multirow{2}{*}{ Microphytobenthos } & 1161.9 & 1023.1 & 1043.1 & 836.6 & 774.4 \\
\hline & $68.4 \%$ & $81.2 \%$ & $81.3 \%$ & $47.3 \%$ & $63.4 \%$ \\
\hline \multirow{2}{*}{ Phytoplankton } & 536.0 & 237.4 & 194.2 & 247.5 & 446.5 \\
\hline & $31.6 \%$ & $18.8 \%$ & $15.1 \%$ & $13.9 \%$ & $36.6 \%$ \\
\hline \multirow{2}{*}{ Seagrass } & - & - & 45.1 & 685.3 & - \\
\hline & & & $3.5 \%$ & $38.8 \%$ & \\
\hline & \multicolumn{5}{|c|}{ Secondary production $\left(\mathrm{mgC} \mathrm{m}^{-2} \mathrm{~d}^{-1}\right)$} \\
\hline Bacteria & 96.8 & 313.2 & 41.3 & 317.5 & 147.7 \\
\hline Meiofauna & 34.9 & 30.6 & 14.5 & 28.4 & 13.6 \\
\hline \multirow[t]{2}{*}{ Macrofauna } & 8.8 & 41.3 & 19.8 & 3.3 & 6.8 \\
\hline & \multicolumn{5}{|c|}{ Production/biomass ratio $\left(d^{-1}\right)$} \\
\hline Meiofauna & 0.03 & 0.28 & 0.04 & 0.08 & 0.08 \\
\hline Macrofauna & 0.007 & 0.002 & 0.003 & $<0.001$ & $<0.001$ \\
\hline
\end{tabular}


Production of macrofauna, ranging 3.3 (seagrass SR) to $41.3 \mathrm{mgC} \mathrm{m}^{-2} \mathrm{~d}^{-1}$ (mudflat SR), was more variable than that of meiofauna, which ranged from 14.5 (seagrass $\mathrm{MO}$ ) to $34.9 \mathrm{mgC} \mathrm{m}^{-2} \mathrm{~d}^{-1}$ (mudflat $\mathrm{MO}$ ) (Table 3). Meiofauna production was higher than those of macrofauna in mudflat MO, seagrass SR and sandflat $\mathrm{SR}$, and relatively similar in mudflat SR and seagrass MO. Meiofauna $\mathrm{P} / \mathrm{B}$ ratios were much higher than those of macrofauna, being from four (mudflat MO) to 800 times higher (seagrass SR). Habitat comparisons highlighted that meiofauna P/B ratios were much higher in the Sylt-Rømø Bight mudflat $\left(0.28 \mathrm{~d}^{-1}\right)$ than in all other habitats (from 0.03 to $0.09 \mathrm{~d}^{-1}$ ). Macrofauna $\mathrm{P} / \mathrm{B}$ ratios were higher in the mudflat MO, mudflat SR and seagrass MO than in the other habitats.

\subsubsection{Transfer efficiency}

In the Marennes-Oléron Bay habitats, the carbon flows from primary food sources (i.e. microphytobenthos, seagrass, phytoplankton, SPOM, SOM and bacteria) to meiofauna (269.9-951.7 $\mathrm{mgC} \mathrm{m} \mathrm{m}^{-2} \mathrm{~d}^{-1}$ ) were much higher than the carbon flows to macrofauna (47.0-173.2 $\mathrm{mgC} \mathrm{m}^{-2} \mathrm{~d}^{-1}$ ) (Fig. 5). The opposite pattern was observed for the Sylt-Rømø Bight habitats with lower carbon flows to meiofauna (115.6$\left.530.5 \mathrm{mgC} \mathrm{m}^{-2} \mathrm{~d}^{-1}\right)$ than to macrofauna $\left(884.3-1584.8 \mathrm{mgC} \mathrm{m}^{-2} \mathrm{~d}^{-1}\right)$. At the habitat scale, the carbon flow from food sources to meiofauna with the lowest trophic level (level II) was high in the mudflat MO (804.4 $\left.\mathrm{mgC} \mathrm{m}^{-2} \mathrm{~d}^{-1}\right)$, seagrass SR (443.6 $\left.\mathrm{mgCm}^{-2} \mathrm{~d}^{-1}\right)$ and mudflat SR (421.5 $\left.\mathrm{mgC} \mathrm{m}^{-2} \mathrm{~d}^{-1}\right)$ (Appendix B.6). A moderate carbon flow was observed in seagrass $\mathrm{MO}\left(234.1 \mathrm{mgC} \mathrm{m}^{-2} \mathrm{~d}^{-1}\right)$ and a particularly low flow was observed in the sandflat SR $\left(97.7 \mathrm{mgC} \mathrm{m}^{-2} \mathrm{~d}^{-1}\right)$. The carbon flow from food sources to macrofauna with the lowest trophic level (level II) was high in the Sylt-Rømø Bight habitats (501.3-1033.5 $\mathrm{mgC} \mathrm{m}^{-2} \mathrm{~d}^{-1}$ ) compared to the moderate flow in the seagrass MO $\left(150.3 \mathrm{mgCm}^{-2} \mathrm{~d}^{-1}\right)$ and the particular low flow in mudflat $\mathrm{MO}$ (42.2 $\mathrm{mgC} \mathrm{m}^{-2} \mathrm{~d}^{-1}$ ) (Appendix B.7).

The carbon flows from meiofauna to higher trophic levels (12.6-39.2 $\left.\mathrm{mgC} \mathrm{m} \mathrm{m}^{-2} \mathrm{~d}^{-1}\right)$ were relatively similar to or slightly higher than those from macrofauna (18.3-30.1 $\mathrm{mgC} \mathrm{m}^{-2} \mathrm{~d}^{-1}$; Table 4) in all habitats, except for mudflat SR. In these habitats, meiofauna represented between $40 \%$ and $66 \%$ of the carbon requirements of higher trophic levels. On the contrary, in the mudflat SR the carbon flows to higher trophic levels were mainly originating from macrofauna $\left(137.1 \mathrm{mgC} \mathrm{m}^{-2} \mathrm{~d}^{-1} ; 74 \%\right)$ with much lower contributions for meiofauna $\left(49.1 \mathrm{mgC} \mathrm{m}^{-2} \mathrm{~d}^{-1} ; 26 \%\right)$.

Large differences were also observed between habitats when comparing the diversity of organisms relying on meiofauna (Table 4). In the mudflat MO flows from meiofauna were equally divided over benthic omnivorous macrofauna (59\%) and benthic fish (41\%), whereas flows from meiofauna to higher trophic levels mostly ended up in one single consumer group in other habitats, benthic omnivorous macrofauna (99\%) in seagrass MO and benthic fishes (>95\%) in Sylt-Rømø Bight habitats. Macrofauna of the seagrass SR and sandflat SR were also mostly assimilated by one group of consumers ( $>95 \%$; carnivorous birds), whereas 
macrofauna had multiple consumers in other habitats (i.e. benthic omnivorous macrofauna, benthic fish and carnivorous birds).

Table 4. Flows from meiofauna (Meio) and macrofauna (Macro) to higher trophic levels ( $\left.\mathrm{mgC} \mathrm{m}^{-2} \mathrm{~d}^{-1}\right)$ in the mudflats, 530 seagrass beds, and sandflat of the Marennes-Oléron Bay (MO) and the Sylt-Rømø Bight (SR). Higher trophic levels are: benthic omnivorous macrofauna (BOM), benthic fish (BFI) and carnivorous birds (CBR).

\begin{tabular}{lcccccccccc}
\hline & \multicolumn{2}{c}{ Mudflat MO } & \multicolumn{2}{c}{ Mudflat SR } & \multicolumn{2}{c}{ Seagrass MO } & \multicolumn{2}{c}{ Seagrass SR } & \multicolumn{2}{c}{ Sandflat SR } \\
\cline { 2 - 11 } & Meio & Macro & Meio & Macro & Meio & Macro & Meio & Macro & Meio & Macro \\
\hline BOM & 7.4 & 4.8 & 49.1 & 1.3 & 0.2 & 0.1 & 19.6 & 8.1 & 39.2 & 0.5 \\
BFI & 5.2 & 2.1 & $<0.1$ & 0.2 & 19.5 & 11.4 & 1.1 & 1.4 & $<0.1$ & 0.4 \\
CBR & - & 11.4 & - & 135.6 & - & 18.6 & - & 9.4 & - & 18.9 \\
\hline
\end{tabular}

532

533

534

535

536

537

538

539

540

541

542

543

544

545

Losses by respiration and egestion were also very different between meiofauna-all integer trophic levels - and macrofauna (Table 5). Meiofauna represented lower respiration (1.7 to 22.3\%) compared to macrofauna (27.0 and 60.3\%). For egestion, the opposite pattern was observed, as it was slightly higher for meiofauna (40.9-90.7\%) compared to that of macrofauna (38.9-68.2\%). Comparisons between habitats highlighted that losses due to respiration of meiofauna were higher in mudflat MO (15.4-19.3\%) and sandflat SR $(12.4-22.3 \%)$ than in other habitats $(<6.5 \%)$. For macrofauna, the loss by respiration was the highest in seagrass MO (60.2-60.3\%) compared to $\mathrm{m}$ other habitats (27.0-48.0\%). Moreover, loss by meiofauna due to egestion was lower in sandflat SR (40.9-73.0\%) than in other habitats (70.0-90.7\%). No clear pattern was observed for relative losses by macrofauna due to egestion.

Table 5. Relative contributions of respiration and egestion to the total meiofauna and macrofauna outflows (\%) in the mudflats, seagrass beds, and sandflat of the Marennes-Oléron Bay (MO) and the Sylt-Rømø Bight (SR). Roman numbers represent the different integer trophic levels that originated from the Lindeman spines (Appendix B.6 and B.7).

\begin{tabular}{lcccccccccc}
\hline & \multicolumn{9}{c}{ Meiofauna } \\
\hline \multicolumn{1}{c}{ Outflow } & \multicolumn{9}{c}{ Respiration } \\
\cline { 2 - 11 } Trophic level & II & III & IV & V & VI & II & III & IV & V & VI \\
\hline Mudflat MO & 19.3 & 17.7 & 15.4 & - & - & 70.0 & 76.1 & 82.9 & - & - \\
Mudflat SR & 1.9 & 1.7 & 1.7 & - & - & 75.7 & 79.6 & 82.3 & - & - \\
Sandflat SR & 12.4 & 17.7 & 22.3 & - & - & 40.9 & 59.7 & 73.0 & - & - \\
Seagrass MO & 5.3 & 5.0 & 6.4 & - & - & 78.4 & 79.5 & 74.2 & - & - \\
Seagrass SR & 4.8 & 4.3 & 4.2 & - & - & 76.2 & 84.8 & 90.7 & - & - \\
\hline
\end{tabular}

\begin{tabular}{|c|c|c|c|c|c|c|c|c|c|c|}
\hline \multirow{3}{*}{$\begin{array}{r}\text { Outflow } \\
\text { Trophic level }\end{array}$} & \multicolumn{10}{|c|}{ Macrofauna } \\
\hline & \multicolumn{5}{|c|}{ Respiration } & \multicolumn{5}{|c|}{ Egestion } \\
\hline & II & III & IV & $\mathrm{V}$ & VI & II & III & IV & $\mathrm{V}$ & VI \\
\hline Mudflat MO & 27.0 & 29.3 & 29.6 & 29.6 & 29.6 & 48.3 & 50.1 & 50.4 & 50.4 & 50.4 \\
\hline Mudflat SR & 39.7 & 37.4 & 42.6 & 45.0 & - & 56.5 & 58.2 & 51.9 & 54.8 & - \\
\hline Sandflat SR & 48.0 & 41.6 & 29.1 & 29.4 & - & 45.1 & 56.0 & 67.5 & 68.2 & - \\
\hline
\end{tabular}




$\begin{array}{lllllllllll}\text { Seagrass MO } & 60.3 & 60.2 & - & - & - & 39.4 & 38.9 & - & - & - \\ \text { Seagrass SR } & 43.0 & 41.6 & 27.6 & 29.2 & - & 53.8 & 53.8 & 53.4 & 56.3 & -\end{array}$

546

547

548

549

550

551

552

553

554

555

556

557

558

559

560

561

562

563

564

565

566

567

568

569

570

As a result, the differences between meiofauna and macrofauna in carbon inflows and outflows (i.e. consumption by higher trophic levels, losses due to respiration and returns due to egestion) led to much higher transfer efficiencies (TEs) of meiofauna (16.2-31.3\%) than of macrofauna (2.5-15.9\%) in all habitats except in mudflat MO (Fig. 7). TE of meiofauna (11.5 $\pm 2.1 \%$ ) in mudflat MO was much lower than TE of macrofauna $(23.1 \pm 2.1 \%)$. Different patterns were observed for the mean transfer efficiencies (MTEs) of integer trophic levels II to IV (Fig. 7), with higher MTEs in mudflat MO (12.7 $\pm 1.2 \%)$, mudflat SR $(11.9 \pm 2.2 \%)$ and seagrass SR $(10.2 \pm 2.2 \%)$ compared to sandflat SR $(8.0 \pm 2.0 \%)$ and seagrass MO $(6.8 \pm 3.6 \%)$.

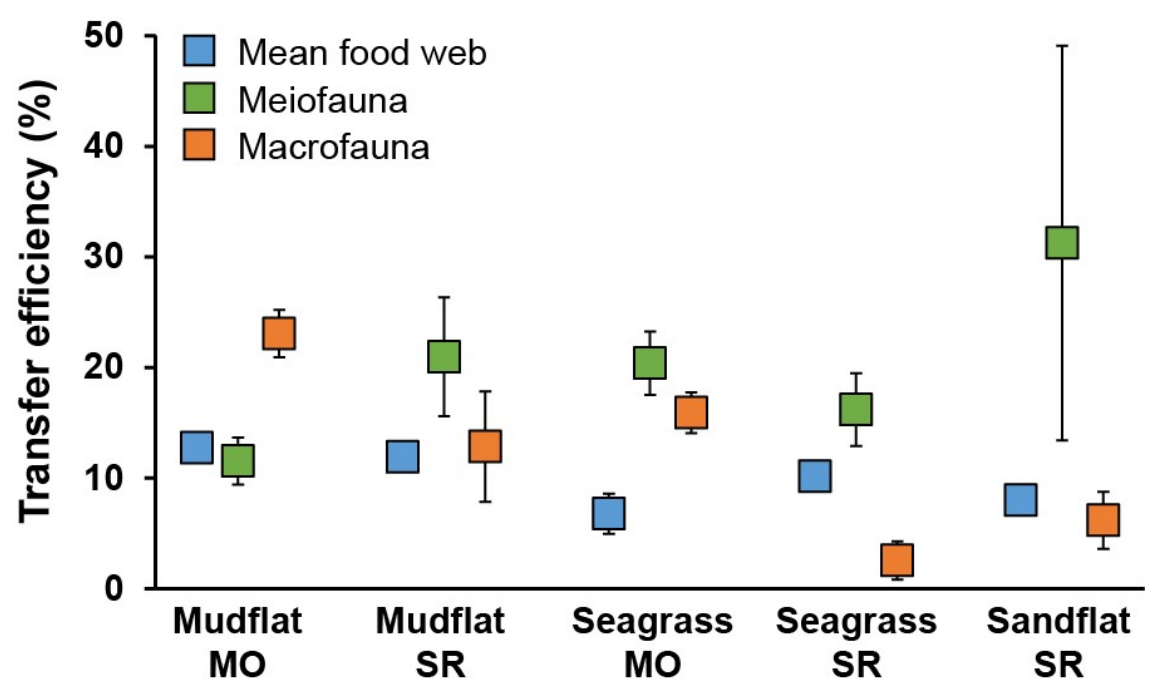

Figure 7. Transfer efficiency (TE) of the whole food web, meiofauna and macrofauna for the mudflats, seagrass beds, and sandflat in the Marennes-Oléron Bay (MO) and the Sylt-Rømø Bight (SR). Mean TE for the food web is the geometric mean from integer trophic level II-IV ( \pm standard deviation; see Appendix B.8). For meiofauna and macrofauna a weighted average is used ( \pm weighted standard deviation).

\subsection{Network analysis}

The food webs of the five studied habitats presented a distinct structure, with an obvious discrimination of the seagrass MO. Seagrass MO had among the lowest values for the average path length (APL), internal ascendency $\left(\mathrm{A}_{\mathrm{i}}\right)$ and Finn cycling index (FCI), whereas the total system throughput (TSTp) was among the highest compared to all other habitats (Fig. 8). Mudflat MO and mudflat SR were characterized by the longest food chain (i.e. high APL), highest internal organization (i.e. high $\mathrm{A}_{\mathrm{i}}$ ), and the highest recycling (i.e. high FCI) whereas seagrass SR and sandflat SR had intermediate values. As demonstrated by their higher values of TSTp, a higher quantity of carbon flows through the food webs of the Marennes-Oléron Bay habitats compared to those of the Sylt-Rømø Bight habitats. 

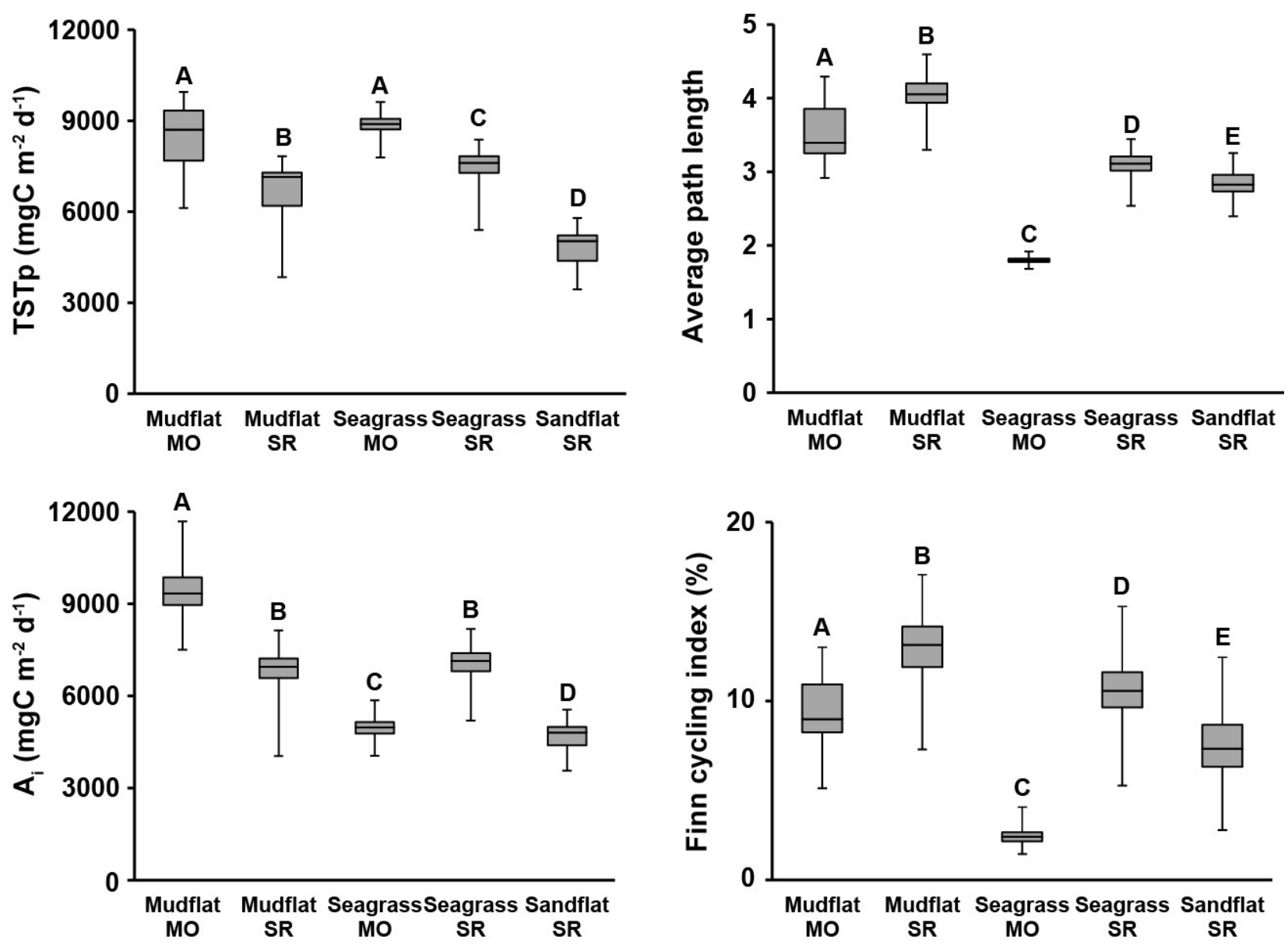

Figure 8. Ecological network analysis indices for the mudflats, seagrass beds and sandflat in the Marennes-Oléron Bay (MO) and the Sylt-Rømø Bight (SR): total system throughput (TSTp; top left), average path length (top right), internal ascendency $\left(\mathrm{A}_{\mathrm{i}}\right.$; bottom left) and Finn cycling index (bottom right). Letters displayed above boxes indicate groups of samples with similar indices using the Cliff's delta statistics (Appendix B.9).

\section{Discussion}

\subsection{Importance of microphytobenthos as a food source for meiofauna}

\subsubsection{Reliance on microphytobenthos}

As evidenced by the five different models, meiofauna mostly relied on microphytobenthos in all habitats, whereas macrofauna relied on a wider variety of food sources. Carbon flows from microphytobenthos indeed represented between 60 (i.e. $62.8 \mathrm{mgC} \mathrm{m}^{-2} \mathrm{~d}^{-1}$ ) and $81 \%$ (i.e. $674.9 \mathrm{mgC} \mathrm{m}^{-2} \mathrm{~d}^{-1}$ ) of the total flows between food sources and meiofauna in the different studied habitats. The high reliance of meiofauna on microphytobenthos confirmed the outcomes of the combined trophic marker approach carried out on the same habitats by van der Heijden et al. (2019). This major role of microphytobenthos in both ecosystems and all habitats highlights the importance of this food source compared to other primary producers, even when the latter have much higher biomass (e.g. seagrass material). Microphytobenthos therefore has a pivotal role as a food source in soft-bottom coastal habitats. 
Importance of microphytobenthos as a food source likely stems from its short turnover times (0.1-7.9 days) and high production (774-1162 $\mathrm{mgC} \mathrm{m}^{-2} \mathrm{~d}^{-1}$ ). More importantly so, these rates (Degré et al., 2006) and microphytobenthos biomass (Lebreton et al., 2009; van der Heijden et al., 2018) are generally much more constant all year round than those of other potential sources, resulting in a reliable food source constantly available. Phytoplankton and seagrass follow strong seasonal fluctuations in biomass and production over a year, mostly blooming during spring and summer seasons, while inputs of detrital material mostly occur in fall and winter (Asmus and Asmus, 1985; Lebreton et al., 2009; Struski and Bacher, 2006; van der Heijden et al., 2018). Moreover, microphytobenthos has a high nutritional quality (Cebrián, 1999), opposed to seagrass material and a fortiori detrital material. Indeed, these latter have a low nutritional value (Vizzini et al., 2002) and are generally characterized by more refractory compounds (i.e. resistant to biological degradation; Klump et al., 1989) and are therefore poorly consumed by both meiofauna and macrofauna (Lebreton et al., 2011a). Meiofauna are known to actively migrate towards (Moens et al., 1999a) or selectively feed on high quality food sources (Azovsky et al., 2005; Estifanos et al., 2013).

\subsubsection{Differences of food source reliance between meiofauna feeding types}

The degree of which meiofauna relied on microphytobenthos in each habitat differed depending on meiofauna feeding types, as demonstrated by the flows and network properties derived from the five habitats models. The various meiofauna feeding types could be gathered in three main groups according to their reliance on microphytobenthos. First group: non-selective deposit feeding nematodes, epigrowth feeding nematodes and benthic copepods, which had a high reliance on microphytobenthos as indicated by their dependency ratios to microphytobenthos (0.73-0.97) and very low omnivory indices $(0.03-0.10)$. For these groups, most of the carbon was originating from microphytobenthos (56 to 91\%) in all habitats (carbon flows from 2 to 303

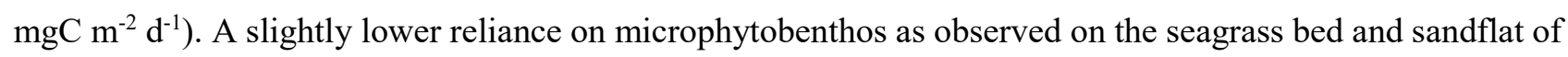
the Sylt-Rømø Bight (56-70\%) may be related to differences in terms of availability, e.g. no biofilm in the sandflat, as productions are in the same order of magnitude in all habitats. The importance of microphytobenthos as a food source for epigrowth feeders and benthic copepods has been demonstrated through grazing experiments before (Rzeznik-Orignac and Fichet, 2012), and is in agreement with the morphology of the buccal cavity of epigrowth feeders, optimized for the consumption of diatoms (Moens and Vincx, 1997a; Wieser, 1953). Epigrowth feeder buccal cavities are fitted with a tooth used to pierce diatoms, making it easier to assimilate them.

Second group: omnivorous/predating nematodes largely relied on carbon of microphytobenthos origin as indicated by their dependency ratios $(0.77-0.94)$. This associated to their relatively higher omnivory index (0.26-0.30) compared to other groups of meiofauna highlighted that these consumers relied both directly and indirectly on microphytobenthos. This indirect reliance on microphytobenthos was linked to the predation on meiofauna from lower trophic groups (i.e., non-selective deposit feeders and epigrowth feeders), themselves feeding on microphytobenthos (Rzeznik-Orignac et al., 2008; Vafeiadou et al., 2014; van Oevelen et al., 2006). 
Third group: selective deposit feeding nematodes, which relied on a larger variety of food sources, as

630

631

632

633

634

635

636

637

638

639

640

641

642

643

644

645

646

647

648

649

650

651

652

653

654

655

656

657

658

659

660

661

662

663

664

reflected by their relatively higher omnivory indices and the similar values of dependency to benthic bacteria, SOM, as well as microphytobenthos. The buccal cavity morphology of selective deposit feeders is adapted to efficiently feed on bacteria (Wieser, 1953), and this high reliance on bacteria was confirmed by carbon flows. Interestingly, bacteria mainly used microphytobenthos and SOM as substrates (Boschker et al., 2000; van der Heijden et al., 2019). As a result, selective deposit feeders rely as well on organic matter primarily produced by microphytobenthos, but in an indirect way, as this organic matter is mostly routed through bacteria before being assimilated by these nematodes. Consequently, although the direct consumption was low, the dependency on microphytobenthos was high, when considering direct and indirect interactions.

The fact that the meiofauna from these different feeding types mostly relied on microphytobenthos while they could access to other food sources clearly highlights that other features of food sources (i.e. quality, productivity) must be considered in addition to biomass when carrying out food web studies. These results also highlight the importance of considering the different feeding types of meiofauna when determining trophic relationships. Indeed, even if we highlighted that meiofauna rely mostly on one single food source (i.e. microphytobenthos), the trophic pathways from this food source when fresh and its ultimate assimilation by meiofauna may vary depending on feeding types (i.e. direct consumption, indirect consumption via grazing on bacteria or predation on other nematodes). This diversity of pathways involved in transfers of organic matter may have implications for the general properties of the food webs (e.g. higher diversity of flows) and changes of meiofauna community structure may affect the functioning of the food webs as well. In addition, even if meiofauna mostly rely on carbon primarily originating from microphytobenthos, some other food sources may also be of high importance to meiofauna given that limited knowledge is available on carbon processing within the meiofauna compartment. Information on direct predator-prey interactions between meiofauna organisms is scarce and meiofaunal feeding modes are known to be flexible (e.g. facultative feeding behavior; (Moens et al., 1999b). As a result, this compartment should be treated in a similar way as macrofauna and aggregating meiofauna trophic groups into a single compartment should be avoided whenever possible.

\subsection{Important role of meiofauna in soft-bottom coastal food webs}

\subsubsection{Evidences about important role of meiofauna}

A large proportion of the energy passed through meiofauna in the different soft-bottom habitats (i.e. $31.2 \%$ on average), besides some important differences: minimum of $10 \%$ in sandflat SR and maximum of $61 \%$ in mudflat MO. The important role of meiofauna as a trophic mediator between primary producers and higher consumers was highlighted by the flows to (116-952 $\mathrm{mgC} \mathrm{m}^{-2} \mathrm{~d}^{-1}$ ) and from meiofauna (13-49 $\left.\mathrm{mgC} \mathrm{m} \mathrm{m}^{-2}\right)$. These flows are in the range of flows to $\left(47-1290 \mathrm{mgC} \mathrm{m}^{-2} \mathrm{~d}^{-1}\right)$ and from macrofauna (18-137 $\mathrm{mgC} \mathrm{m} \mathrm{d}^{-1}$ ). Focusing merely on the contribution of meiofauna and macrofauna to the diet of higher trophic 
level consumers (i.e. benthic omnivorous macrofauna, benthic fish and carnivorous birds) the relative contribution of meiofauna as a food source to higher trophic levels ranges from 26 to $66 \%$. However, distinct patterns were observed between habitats about the proportion of energy passing through meiofauna and macrofauna. At the ecosystem scale, more energy passed through macrofauna (65-70\%) when compared to the meiofauna (10-32\%) in the Sylt-Rømø Bight, while the opposite pattern was observed in the MarennesOléron Bay (i.e. macrofauna: $5-18 \%$, meiofauna: $30-61 \%$ ). This is very likely related to the much larger biomass of macrofauna (100 to 200 times more) in the Sylt-Rømø Bight than in the Marennes-Oléron Bay. Despite the smaller amount of energy that passed through meiofauna in seagrass SR and sandflat SR, a larger proportion of the energy for higher trophic levels originated from meiofauna (meiofauna: 52-66\%; macrofauna: 34-48\%). At the habitat scale, a larger proportion of energy passed through meiofauna in the mudflat of the Marennes-Oléron Bay (61\%) compared to all other habitats (10-32\%). Consequently, a much lower amount of energy passed through macrofauna in mudflat MO (5\%), while biomass of meiofauna and macrofauna were similar. This much higher amount of energy transiting through meiofauna is very likely related to the close connection between meiofauna and microphytobenthos, which is very productive and highly available in this habitat as it forms a biofilm at the sediment surface. In addition, more diverse consumer groups relied on meiofauna in the mudflat of the Marennes-Oléron Bay, whereas meiofauna was consumed by one dominant higher trophic level consumer in all other habitats, i.e. benthic fish (seagrass MO) or benthic omnivorous macrofauna (Sylt-Rømø Bight habitats).

\subsubsection{How can meiofauna play this important role?}

The important role of meiofauna in the functioning of the five habitats is very likely related to their high production (14-35 $\left.\mathrm{mgC} \mathrm{m}^{-2} \mathrm{~d}^{-1}\right)$ and $\mathrm{P} / \mathrm{B}$ ratios $\left(0.03-0.28 \mathrm{~d}^{-1}\right)$. Indeed, meiofauna production was either similar (in the seagrass MO and in the mudflat SR), or even higher (2 to 9 times, in all other habitats), than macrofauna production. These productions were generally in agreement with previous estimations (10 to $80 \mathrm{mgC} \mathrm{m}^{-2} \mathrm{~d}^{-1}$ ) (Chardy and Dauvin, 1992; Danovaro et al., 2002; Escaravage et al., 1989). The high production of meiofauna combined with similar and/or lower biomass compared to macrofauna resulted in much higher $\mathrm{P} / \mathrm{B}$ ratios than for the macrofauna, i.e. from 4 to 1000 times. Higher production and $\mathrm{P} / \mathrm{B}$ ratios of meiofauna compared to macrofauna is known to be related to their higher turn-over rates (at least five times higher than that of macrofauna: Gerlach, 1971; Moens and Vincx, 1997b) and higher weight-specific metabolic rates (up to 21 times higher than for macrofauna: Kuipers et al., 1981).

Meiofauna also play a major role in the different studied food webs as trophic mediator, as confirmed by the transfer efficiency of meiofauna (i.e. $20 \%$ on average) which was higher than the transfer efficiency of macrofauna (i.e. $12 \%$ on average) and much higher than the mean transfer efficiency of the whole food webs (i.e. 10\% on average). Meiofauna also have a high nutritional value (Coull, 1999) and their concentration in the surface sediment layer make them a very available and valuable food source to consumers (Castel et al., 1989; Leduc and Probert, 2011; van der Heijden et al., 2018). The important role of meiofauna 
as a food source for juvenile benthic feeding fish (e.g. mullets, gobies, flatfish, grunts and croakers) was demonstrated in mudflats (Carpentier et al., 2014; Gordon and Duncan, 1979; Lassere et al., 1975; Smith and Coull, 1987; Smith et al., 1984), sandflats (Castel and Lasserre, 1982; Gee, 1987; Hicks, 1984; Pihl, 1985) and salt marshes (Lebreton et al., 2013, 2011b). As a result, meiofauna can help fulfil the nutritional needs of higher trophic level organisms, that are eventually harvestable by humans. However, the exact fate of meiofauna remains unclear (Giere, 2009) and further research should focus on the flows from meiofauna to higher trophic levels in food webs. Meiofauna should at least not be neglected in coastal ecosystem assessments and should be treated similarly to macrofauna.

\subsection{Close relationship between food web efficiency and assimilation of high-quality food sources}

Mudflat MO, mudflat SR and seagrass SR were the most efficient food webs with a high mean transfer efficiency (MTE: 10.2-12.7\%; Heymans et al., 2014), associated with the highest internal ascendency ( $\mathrm{A}_{\mathrm{i}}:$ 6946-9339 $\mathrm{mgC} \mathrm{m}^{-2} \mathrm{~d}^{-1}$; Baird et al., 2007) and the highest average path length (APL: 3.1-4.1; Hutchinson, 1959; Slobodkin, 1960). These high MTEs are explained by the structure of the studied food webs, in which the carbon is constrained to flow through specific trophic pathways, resulting in the high $\mathrm{A}_{\mathrm{i}}$. Thus, the link between a predator and its main prey items is based on preferences whereas indirect consumption on the same prey is limited. In this way the losses of carbon by respiration, egestion and export are limited, as suggested by the APL, and the carbon flows through longer and more efficient trophic chains. The highest efficiencies of these three habitats are very likely related to the large flows from high quality food sources (836-996 $\mathrm{mgC} \mathrm{m}^{-2} \mathrm{~d}^{-1}$ ), that fulfill the energy requirements of organisms, prevent them from diversifying their diet and favor higher assimilation. In the core of this efficient trophic chain is the meiofauna that have consumed up to $40 \%$ of the GPP and that are among the main prey for higher trophic levels. The lower efficiency in the sandflat SR was related to lower microphytobenthos production and a resulting lower input from this high-quality food source to primary consumers $\left(607 \mathrm{mgC} \mathrm{m}^{-2} \mathrm{~d}^{-1}\right)$. However, the energy was very efficiently transferred from primary consuming meiofauna to higher trophic levels partially related to the high relative biomass of omnivores/predating nematodes. As reported by Campanyà-Llovet et al. (2017), the lowest trophic levels have the strongest response to changes in food quality. Thus, caution should be taken when aggregating smaller organisms in the lower trophic levels of food webs, e.g. meiofauna, since these organisms generally assimilate large proportions of the flows coming from high-quality food sources.

The link between food web efficiency and assimilation of high-quality primary food sources is less clear in seagrass MO. Low MTE (6.8\%), $\mathrm{A}_{\mathrm{i}}\left(4974 \mathrm{mgC} \mathrm{m}^{-2} \mathrm{~d}^{-1}\right)$ and APL (1.8) clearly demonstrate a low efficiency, however, the flows from primary producers to primary consumers were dominated by high-quality food sources (70.5\%), despite the low input when compared to other habitats $\left(391 \mathrm{mgC} \mathrm{m}^{-2} \mathrm{~d}^{-1}\right)$. This could be related to the lower proportion of available carbon that is transferred to higher trophic levels, as indicated by the low APL. Further investigations are needed to clarify this point, to determine if this is for ecological (e.g. low recycling or high export) or mathematical reasons (i.e. the topology of the model). The recycling was very low in seagrass $\mathrm{MO}$, as highlighted by the very low FCI $(2.4 \%)$ when compared to other habitats $(7.3-$ 
13.1\%). This low recycling may be related to the poorly used detrital pool in seagrass MO (26\%) when compared to other habitats (62-80\%). The food web efficiency might have been affected by this low recycling, since food web efficiency includes both the efficiency of energy transfers from primary producers to herbivores and then carnivores as well as from detrital material to detritivores and then carnivores. Therefore, the low consumption of detritus by detritivores might have an indirect effect on the lower transfer efficiency of trophic level II and III in seagrass MO.

\section{Conclusion}

The analysis of five coastal food web models highlighted the importance of the trophic pathway between microphytobenthos and meiofauna in soft-bottom intertidal habitats. Microphytobenthos was indeed the most important primary producer and the most important food resource for meiofauna in these habitats (63-675 $\mathrm{mgC} \mathrm{m} \mathrm{m}^{-2} \mathrm{~d}^{-1}$ ), even when high loads of seagrass material were present. The important role of meiofauna was highlighted by their high throughput (average: $31.2 \%$ ), high production (14-35 $\mathrm{mgC} \mathrm{m}^{-2} \mathrm{~d}^{-1}$ ) and transfer efficiency (11-28\%). As a result, meiofauna are responsible for a large part of the production as well as for the carbon flows from microphytobenthos towards higher trophic levels, and thus are very important in the functioning of intertidal soft-bottom habibats. On the contrary, the slower-growing macrofauna are more accountable for energy storage and rely on a larger diversity of food sources. Therefore, these two compartments appear to provide complementary ecosystem functions. They should thus be considered with the same level of precision when building food web models, especially since a close positive relationship was highlighted between the assimilation of high-quality food sources by primary consumers, e.g. meiofauna and macrofauna, and the overall food web efficiency.

The close link between microbiota and meiofauna and the use of available primary sources (i.e. microphytobenthos) by meiofauna make these consumers a key compartment in the functioning of food webs in soft-bottom habitats (Schratzberger and Ingels, 2017). Although most trophic groups of meiofauna revealed a high reliance on microphytobenthos in all habitats, through direct (herbivory) or indirect (carnivory) flows, some meiofauna trophic groups relied on bacteria and SOM, with direct consequences on the carbon use and its distribution within the food web. The diversity in feeding behavior and their significance in the carbon flow justify the partitioning of meiofauna into different compartments, as traditionally done for macrofauna in most food web studies. We therefore argue that feeding types of meiofauna should be considered as separate compartments in future studies. Coupling state-of-the-art methods (i.e. molecular techniques, trophic markers and stomach content) should be commonly used to quantify carbon flows from/to meiofauna with higher precision and thus refine the role of this key compartment in the functioning of coastal habitats.

\section{ACKNOWLEDGEMENTS}

This study forms part of the Ph.D. thesis of L. van der Heijden. This work was financially supported by the University of La Rochelle through a grant provided by the French Ministry for Higher Education and 
Research. This work was supported by the CNRS through the CNRS research chair provided to B. Lebreton. Financial support was provided by the Alfred Wegener Institute Helmholtz Centre for Polar and Marine Research, as well as the University of La Rochelle (Mobility for doctoral students), the German Academic Exchange Service (DAAD: short-term research grant, 2017, no. 57314023), and Campus France and the DAAD in the framework of the PHC PROCOPE program (2018-2019, grant no. 40443SB). We acknowledge P. Pineau, B. Hussel, S. Horn, M. Burgdorf, M. Paar, D. Fichet and N. Lachaussée for their support during fieldwork and G. Guillou, Q. Bernier, V. Adrian and C. Labrune for their support in the analyses. Finally, L. van der Heijden thanks G. Blanchard, a member of his Ph.D. committee, for his guidance, as well as the two anonymous reviewers whose comments greatly improved the manuscript. The views expressed in this article are those of the author(s) and do not necessarily represent the views or policies of the U.S. Environmental Protection Agency.

\section{REFERENCES}

Asmus, H., 1987. Secondary production of an intertidal mussel bed community related to its storage and turnover compartments. Mar. Ecol. Prog. Ser. 39, 251-266. https://doi.org/10.3354/meps039251

Asmus, H., Asmus, R., 2000. Material exchange and food web of seagrass beds in the Sylt-Rømø Bight: how significant are community changes at the ecosystem level? Helgol. Mar. Res. 54, 137-150. https://doi.org/10.1007/s101520050012

Asmus, H., Asmus, R.M., 2005. Significance of suspension-feeder systems on different spatial scales, in: Dame, R.F., Olenin, S. (Eds.), The Comparative Roles of Suspension-Feeders in Ecosystems. Springer Netherlands, pp. 199-219. https://doi.org/10.1007/1-4020-3030-4_12

Asmus, H., Asmus, R.M., 1998. The role of macrobenthic communities for sediment-water material exchange in the Sylt-Rømø tidal basin. Senckenbergiana Maritima 29, 111-119. https://doi.org/10.1007/BF03043949

Asmus, H., Asmus, R.M., 1993. Phytoplankton-mussel bed interactions in intertidal ecosystems, in: Dame, R.F. (Ed.), Bivalve Filter Feeders. Springer, Berlin, Germany, pp. 57-84.

Asmus, H., Asmus, R.M., 1985. The importance of grazing food chain for energy flow and production in three intertidal sand bottom communities of the northern Wadden Sea. Helgoländer Meeresunters. 39, 273-301. https://doi.org/10.1007/BF01992775

Asmus, R.M., Bauerfeind, E., 1994. The microphytobenthos of Königshafen - spatial seasonal distribution on a sandy tidal flat. Helgolander Meeresunters. 276, 257-276.

Azovsky, A.I., Saburova, M.A., Chertoprood, E.S., Polikarpov, I.G., 2005. Selective feeding of littoral harpacticoids on diatom algae: Hungry gourmands? Mar. Biol. 148, 327-337. https://doi.org/10.1007/s00227-005-0086-2

Baird, D., Asmus, H., Asmus, R.M., 2007. Trophic dynamics of eight intertidal communities of the Sylt-Rømø Bight ecosystem, northern Wadden Sea. Mar. Ecol. Prog. Ser. 351, $25-41$. https://doi.org/10.3354/meps07137

Baird, D., Asmus, H., Asmus, R.M., 2004a. Energy flow of a boreal intertidal ecosystem, the Sylt-Rømø 
Bight. Mar. Ecol. Prog. Ser. 279, 45-61.

Baird, D., Christian, R.R., Peterson, C.H., Johnson, G.A., 2004b. Consequences of hypoxia on estuarine ecosystem function: Energy diversion from consumers to microbes. Ecol. Appl. 14, 805-822.

Baird, D., Fath, B.D., Ulanowicz, R.E., Asmus, H., Asmus, R.M., 2009. On the consequences of aggregation and balancing of networks on system properties derived from ecological network analysis. Ecol. Modell. 220, 3465-3471. https://doi.org/10.1016/j.ecolmodel.2009.09.008

Baird, D., Luczkovich, J., Christian, R.R., 1998. Assessment of spatial and temporal variability in ecosystem attributes of the St Marks national wildlife refuge, Apalachee Bay, Florida. Estuar. Coast. Shelf Sci. https://doi.org/10.1006/ecss.1998.0360

Baird, D., Ulanowicz, R.E., 1993. Comparative study on the trophic structure, cycling and ecosystem properties of four tidal estuaries. Mar. Ecol. Prog. Ser. 99, 221-237.

Baird, D., Ulanowicz, R.E., 1989. The seasonal dynamics of the Chesapeake Bay ecosystem. Ecol. Monogr. $59,329-364$.

Blanchard, G.F., 1991. Measurement of meiofauna grazing rates on microphytobenthos: is primary production a limiting factor? J. Exp. Mar. Bio. Ecol. 147, 37-46. https://doi.org/10.1016/00220981(91)90035-U

Boschker, H.T.S., Wielemaker, A., Schaub, B.E.M., Holmer, M., 2000. Limited coupling of macrophyte production and bacterial carbon cycling in the sediments of Zostera spp. meadows. Mar. Ecol. Prog. Ser. 203, 181-189. https://doi.org/10.3354/meps203181

Campanyà-Llovet, N., Snelgrove, P.V.R., Parrish, C.C., 2017. Rethinking the importance of food quality in marine benthic food webs. Prog. Oceanogr. 156, 240-251. https://doi.org/10.1016/j.pocean.2017.07.006

Carman, K.R., Fry, B., 2002. Small-sample methods for $\delta^{13} \mathrm{C}$ and $\delta^{15} \mathrm{~N}$ analysis of the diets of marsh meiofaunal species using natural-abundance and tracer-addition isotope techniques. Mar. Ecol. Prog. Ser. 240, 85-92. https://doi.org/10.3354/meps240085

Carpentier, A., Como, S., Dupuy, C., Lefrançois, C., Feunteun, E., 2014. Feeding ecology of Liza spp. in a tidal flat: Evidence of the importance of primary production (biofilm) and associated meiofauna. J. Sea Res. 92, 86-91. https://doi.org/10.1016/j.seares.2013.10.007

Castel, J., Labourg, P.J., Escaravage, V., Auby, I., Garcia, M.E., 1989. Influence of seagrass beds and oyster parks on the abundance and biomass patterns of meio- and macrobenthos in tidal flats. Estuar. Coast. Shelf Sci. 28, 71-85. https://doi.org/10.1016/0272-7714(89)90042-5

Castel, J., Lasserre, P., 1982. Régulation biologique du meiobenthos d'un écosystème lagunaire par un alevinage expérimental en soles (Solea vualgaris). Oceanol. Acta, Spec. issue 243-252.

Cebrián, J., 1999. Patterns in the fate of production in plant communities. Am. Nat. 154, 449-468. https://doi.org/10.1086/303244

Chardy, P., Dauvin, J.C., 1992. Carbon flows in a subtidal fine sand community from the western English Channel: a simulation analysis. Mar. Ecol. Prog. Ser. 81, 147-161. https://doi.org/10.3354/meps081147 Christensen, V., 1995. Ecosystem maturity - towards quantification. Ecol. Modell. 77, 3-32. 
https://doi.org/10.1016/0304-3800(93)E0073-C

Cliff, N., 1993. Dominance statistics: Ordinal analyses to answer ordinal questions. Psychol. Bull. 114, 494509.

Couch, C.A., 1989. Carbon and nitrogen stable isotopes of meiobenthos and their food resources. Estuar. Coast. Shelf Sci. 28, 433-441. https://doi.org/10.1016/0272-7714(89)90090-5

Coull, B.C., 1999. Role of meiofauna in estuarine soft-bottom habitats. Austral Ecol. 24, 327-343. https://doi.org/10.1046/j.1442-9993.1999.00979.x

Coull, B.C., 1990. Are members of the meiofauna food for higher trophic levels? Trans. Am. Microsc. Soc. 109, 233. https://doi.org/10.2307/3226794

Danovaro, R., Gambi, C., Mirto, S., 2002. Meiofaunal production and energy transfer efficiency in a seagrass Posidonia oceanica bed in the western Mediterranean. Mar. Ecol. Prog. Ser. 234, 95-104. https://doi.org/10.3354/meps234095

Danovaro, R., Scopa, M., Gambi, C., Fraschetti, S., 2007. Trophic importance of subtidal metazoan meiofauna: Evidence from in situ exclusion experiments on soft and rocky substrates. Mar. Biol. 152, 339-350. https://doi.org/10.1007/s00227-007-0696-y

de la Vega, C., Schückel, U., Horn, S., Kröncke, I., Asmus, R., Asmus, H., 2018. How to include ecological network analysis results in management? A case study of three tidal basins of the Wadden Sea, south-eastern North Sea. Ocean Coast. Manag. 163, 401-416. https://doi.org/10.1016/j.ocecoaman.2018.07.019

Degré, D., Leguerrier, D., Armynot du Chatelet, E., Rzeznik, J., Auguet, J.C., Dupuy, C., Marquis, E., Fichet, D., Struski, C., Joyeux, E., Sauriau, P.G., Niquil, N., 2006. Comparative analysis of the food webs of two intertidal mudflats during two seasons using inverse modelling: Aiguillon Cove and Brouage Mudflat, France. Estuar. Coast. Shelf Sci. 69, 107-124. https://doi.org/10.1016/j.ecss.2006.04.001

Escaravage, V., García, M., Castel, J., 1989. The distribution of meiofauna and its contribution to detritic pathways in tidal flats (Arcachon Bay, France). Sci. Mar. 53, 551-559.

Estifanos, T.K., Traunspurger, W., Peters, L., 2013. Selective feeding in nematodes: A stable isotope analysis of bacteria and algae as food sources for free-living nematodes. Nematology 15, 1-13. https://doi.org/10.1163/156854112X639900

Finn, J.T., 1976. Measures of ecosystem structure and function derived from analysis of flow. J. Theor. Biol. $56,363-380$.

Gätje, C., Reise, K., 1998. Ökosystem Wattenmeer: Austausch-, Transport-und Stoffumwandlungsprozesse. Springer, Berlin, Germany.

Gee, J.M., 1987. Impact of epibenthic predation on estuarine intertidal harpacticoid copepod populations. Mar. Biol. 96, 497-510. https://doi.org/10.1007/BF00397967

Gerlach, S.A., 1971. On the importance of marine meiofauna for benthos communities. Oecologia 6, 176190. https://doi.org/10.1007/BF00345719

Giere, O., 2009. Meiobenthology: the microscopic motile fauna of aquatic sediments, 2nd ed. Springer- 
Verlag, Berlin, Germany.

Gordon, J.D.M., Duncan, J.A.R., 1979. Some notes on the biology of the snake blenny, Lumpenus lampretaeformis on the west coast of Scotland. J. Mar. Biol. Assoc. United Kingdom 59, 413-419. https://doi.org/10.1017/S0025315400042727

Gouleau, D., Jouanneau, J.M., Weber, O., Sauriau, P.G., 2000. Short- and long-term sedimentation on Montportail-Brouage intertidal mudflat, Marennes-Oleron Bay (France). Cont. Shelf Res. 20, 15131530. https://doi.org/10.1016/S0278-4343(00)00035-2

Guesnet, V., Lassalle, G., Chaalali, A., Kearney, K., Saint-Béat, B., Karimi, B., Grami, B., Tecchio, S., Niquil, N., Lobry, J., 2015. Incorporating food-web parameter uncertainty into Ecopath-derived ecological network indicators. Ecol. Modell. 313, 29-40. https://doi.org/10.1016/j.ecolmode1.2015.05.036

Haubois, A.G., Sylvestre, F., Guarini, J.M., Richard, P., Blanchard, G.F., 2005. Spatio-temporal structure of the epipelic diatom assemblage from an intertidal mudflat in Marennes-Oléron Bay, France. Estuar. Coast. Shelf Sci. 64, 385-394. https://doi.org/10.1016/j.ecss.2005.03.004

Heip, C.H.R., Huys, R., Alkemade, R., 1992. Community structure and functional roles of meiofauna in the North Sea. Netherlands J. Aquat. Ecol. 26, 31-41. https://doi.org/10.1007/BF02298026

Heip, C.H.R., Smol, N., 1975. On the importance of Protohydra leuckarti as a predator of meiobenthic populations, in: Persoone, G., Jaspers, E. (Eds.), 10th European Symposium on Marine Biology. Univerca Press, Wetteren, Ostend, Belgium, pp. 285-296.

Herman, P.M.J., Vranken, G., 1988. Studies of the life-history and energetics of marine and brackish-water nematodes. Oecologia 77, 457-463.

Heymans, J.J., Coll, M., Libralato, S., Morissette, L., Christensen, V., 2014. Global patterns in ecological indicators of marine food webs: A modelling approach. PLoS One 9. https://doi.org/10.1371/journal.pone.0095845

Hicks, G.R.F., 1984. Spatio-temporal dynamics of a meiobenthic copepod and the impact of predationdisturbance. J. Exp. Mar. Bio. Ecol. 81, 47-72. https://doi.org/10.1016/0022-0981(84)90223-5

Hutchinson, G.E., 1959. Homage to Santa Rosalia or why are there so many kinds of animals? Am. Nat. 93, $145-159$.

Johnson, G.A., Niquil, N., Asmus, H., Bacher, C., Asmus, R., Baird, D., 2009. The effects of aggregation on the performance of the inverse method and indicators of network analysis. Ecol. Modell. 220, 34483464. https://doi.org/10.1016/j.ecolmodel.2009.08.003

Klump, D., Howard, R., Pollard, P., 1989. Trophodynamics and nutritional ecology of seagrass communities, in: Larkum, A., McComb, A., Shepherd, S. (Eds.), Biology of Seagrasses. Elsevier, Amsterdam, the Netherlands, pp. 394-457.

Kones, J.K., Soetaert, K., van Oevelen, D., Owino, J.O., Mavuti, K., 2006. Gaining insight into food webs reconstructed by the inverse method. J. Mar. Syst. 60, 153-166. https://doi.org/10.1016/j.jmarsys.2005.12.002

Kuipers, B.R., de Wilde, P.A.W.J., Creutzberg, F., 1981. Energy flow in a tidal flat ecosystem. Mar. Ecol. 
Prog. Ser. 5, 215-221. https://doi.org/10.3354/meps005215

Lassere, P., Renaud-Mornant, J., Castel, J., 1975. Metabolic activities of meiofaunal communities in a semi-enclosed lagoon. Possibilities of trophic competition between meiofauna and mugilid fish, in: Personne, G., Jaspers, E. (Eds.), Tenth European Symposium on Marine Biology, Ostend, Belgium, September 1975, 2. Universal Press, Wetteren, Belgium, pp. 393-414.

Latham, L.G., 2006. Network flow analysis algorithms. Ecol. Modell. 192, 586-600. https://doi.org/10.1016/j.ecolmodel.2005.07.029

Lau, M.K., Borrett, S.R., Hines, D.E., Singh, P., 2017. Tools for Ecological Network Analysis.

Lebreton, B., 2009. Analyse de la structure et du fonctionnement du reseau trophique d'un herbier par approche multi-traceurs: tracage isotopique naturel et profiles acides gras. University of La Rochelle, France.

Lebreton, B., Richard, P., Galois, R., Radenac, G., Brahmia, A., Colli, G., Grouazel, M., André, C., Guillou, G., Blanchard, G.F., 2012. Food sources used by sediment meiofauna in an intertidal Zostera noltii seagrass bed: A seasonal stable isotope study. Mar. Biol. 159, 1537-1550. https://doi.org/10.1007/s00227-012-1940-7

Lebreton, B., Richard, P., Galois, R., Radenac, G., Pfléger, C., Guillou, G., Mornet, F., Blanchard, G.F., 2011a. Trophic importance of diatoms in an intertidal Zostera noltii seagrass bed: Evidence from stable isotope and fatty acid analyses. Estuar. Coast. Shelf Sci. 92, 140-153. https://doi.org/10.1016/j.ecss.2010.12.027

Lebreton, B., Richard, P., Guillou, G., Blanchard, G.F., 2013. Trophic shift in young-of-the-year Mugilidae during salt-marsh colonization. J. Fish Biol. 82, 1297-1307. https://doi.org/10.1111/jfb.12069

Lebreton, B., Richard, P., Parlier, E.P., Guillou, G., Blanchard, G.F., 2011b. Trophic ecology of mullets during their spring migration in a European saltmarsh: A stable isotope study. Estuar. Coast. Shelf Sci. 91, 502-510. https://doi.org/10.1016/j.ecss.2010.12.001

Lebreton, B., Richard, P., Radenac, G., Bordes, M., Bréret, M., Arnaud, C., Mornet, F., Blanchard, G.F., 2009. Are epiphytes a significant component of intertidal Zostera noltii beds? Aquat. Bot. 91, 82-90. https://doi.org/10.1016/j.aquabot.2009.03.003

Leduc, D., Probert, P.K., 2011. Small-scale effect of intertidal seagrass (Zostera muelleri) on meiofaunal abundance, biomass, and nematode community structure. J. Mar. Biol. Assoc. United Kingdom 91, 579-591. https://doi.org/10.1017/S0025315410001645

Leduc, D., Probert, P.K., Duncan, A., 2009. A multi-method approach for identifying meiofaunal trophic connections. Mar. Ecol. Prog. Ser. 383, 95-111. https://doi.org/10.3354/meps07991

Leguerrier, D., Degré, D., Niquil, N., 2007. Network analysis and inter-ecosystem comparison of two intertidal mudflat food webs (Brouage Mudflat and Aiguillon Cove, SW France). Estuar. Coast. Shelf Sci. 74, 403-418. https://doi.org/10.1016/j.ecss.2007.04.014

Leguerrier, D., Niquil, N., Boileau, N., Rzeznik, J., Sauriau, P.G., Le Moine, O., Bacher, C., 2003. Numerical analysis of the food web of an intertidal mudflat ecosystem on the Atlantic coast of France. Mar. Ecol. Prog. Ser. 246, 17-37. https://doi.org/10.3354/meps246017 
Lindeman, R.L., 1942. The trophic-dynamic aspect of ecology. Ecology 23, 399-417.

Macbeth, G., Razumiejczyk, E., Ledesma, R.D., 2010. Cliff's Delta Calculator: A non-parametric effect size program for two groups of observations. Univ. Psychol. 10, 545-555. https://doi.org/10.11144/javeriana.upsy10-2.cdep

Magnhagen, C., Northcote, T.G., Gregory, R.S., 2007. Diet differentiation in three species of juvenile Pacific salmon (Oncorhynchus spp.) in estuarine tidal channels and laboratory experiments. Can. Tech. Rep. Fish. Aquat. Sci. 2758, vi+20pp.

Marcarelli, A.M., Baxter, C.V., Mineau, M.M., Hall, R.O., 2011. Quantity and quality: unifying food web and ecosystem perspectives on the role of resource subsidies in freshwaters. Ecology 92, 1215-1225. https://doi.org/10.1890/11-1136.1

McIntyre, A.D., Murison, D.J., 1973. The meiofauna of a flatfish nursery ground. J. Mar. Biol. Assoc. United Kingdom 53, 93-118. https://doi.org/10.1017/S0025315400056666

Moens, T., Braeckman, U., Derycke, S., Fonseca, G., Gallucci, F., Gingold, R., Guilini, K., Ingels, J., Leduc, D., Vanaverbeke, J., Van Colen, C., Vanreusel, A., Vincx, M., 2013. Ecology of free-living marine nematodes, in: Handbook of Zoology: Gastrotricha, Cycloneuralia and Gnathifera, Vol. 2: Nematoda. pp. 109-152. https://doi.org/10.1515/9783110274257.109

Moens, T., Dos Santos, G.A.P., Thompson, F., Swings, J., Fonsêca-Genevois, V., Vincx, M., De Mesel, I., 2005. Do nematode mucus secretions affect bacterial growth? Aquat. Microb. Ecol. 40, 77-83. https://doi.org/10.3354/ame040077

Moens, T., Moodley, L., Steyaert, M., van Colen, C., van Oevelen, D., Boschker, H.T.S., Herman, P.M.J., Middelburg, J.J., Soetaert, K., Ysebaert, T., Vincx, M., 2011. The structure and functional roles of tidal flat meiobenthos. Asp. Coast. Res. Contrib. to LOICZ Netherlands Flanders 171-184.

Moens, T., Vafeiadou, A.M., De Geyter, E., Vanormelingen, P., Sabbe, K., De Troch, M., 2014. Diatom feeding across trophic guilds in tidal flat nematodes, and the importance of diatom cell size. J. Sea Res. 92, 125-133. https://doi.org/10.1016/j.seares.2013.08.007

Moens, T., Verbeeck, L., de Maeyer, A., Swings, J., Vincx, M., 1999a. Selective attraction of marine bacterivorous nematodes to their bacterial food. Mar. Ecol. Prog. Ser. 176, 165-178. https://doi.org/10.3354/meps176165

Moens, T., Verbeeck, L., Vincx, M., 1999b. Feeding biology of a predatory and a predatory nematode (Enoploides longispiculosus and Adoncholaimus fuscus). Mar. Biol. 134, 585-593. https://doi.org/10.1007/s002270050573

Moens, T., Vincx, M., 1997a. Observations on the feeding ecology of estuarine nematodes. J. Mar. Biol. Assoc. United Kingdom 77, 211-227. https://doi.org/10.1080/02541858.1980.11447695

Moens, T., Vincx, M., 1997b. A state of the art on meiofaunal respiration and production. Second Netw. Meet. Eur. Netw. Integr. Mar. Syst. Anal. FWO-Vlaanderen. 347-361.

Montagna, P.A., Blanchard, G.F., Dinet, A., 1995. Effect of production and biomass of intertidal microphytobenthos on meiofaunal grazing rates. J. Exp. Mar. Bio. Ecol. 185, 149-165. https://doi.org/10.1016/0022-0981(94)00138-4 
Niquil, N., Saint-Béat, B., Johnson, G.A., Soetaert, K., van Oevelen, D., Bacher, C., Vézina, A.F., 2011. Inverse modeling in modern ecology and application to coastal ecosystems, in: Treatise on Estuarine and Coastal Science. Elsevier Inc., pp. 115-133. https://doi.org/10.1016/B978-0-12-374711-2.00906-2

Pacella, S.R., Lebreton, B., Richard, P., Phillips, D., DeWitt, T.H., Niquil, N., 2013. Incorporation of diet information derived from Bayesian stable isotope mixing models into mass-balanced marine ecosystem models: A case study from the Marennes-Oléron Estuary, France. Ecol. Modell. 267, 127-137. https://doi.org/10.1016/j.ecolmodel.2013.07.018

Pascal, P.Y., Bocher, P., Lefrançois, C., Nguyen, H.T., Chevalier, J., Dupuy, C., 2019. Meiofauna versus macrofauna as a food resource in a tropical intertidal mudflat. Mar. Biol. 166, 1-11. https://doi.org/10.1007/s00227-019-3588-z

Pascal, P.Y., Dupuy, C., Richard, P., Rzeznik-Orignac, J., Niquil, N., 2008. Bacterivory of a mudflat nematode community under different environmental conditions. Mar. Biol. 154, 671-682. https://doi.org/10.1007/s00227-008-0960-9

Pihl, L., 1985. Food selection and consumption of mobile epibenthic fauna in shallow marine areas. Mar. Ecol. Prog. Ser. 22, 169-179. https://doi.org/10.3354/meps022169

Romano, J., Kromrey, J.D., Coraggio, J., Skowronek, J., Devine, L., 2006. Exploring methods for evaluating group differences on the NSSE and other surveys: Are the t-test and Cohen's $d$ indices the most appropriate choices? Annu. Meet. South. Assoc. Institutional Res. 14-17. https://doi.org/10.1017/CBO9781107415324.004

Rzeznik-Orignac, J., Boucher, G., Fichet, D., Richard, P., 2008. Stable isotope analysis of food source and trophic position of intertidal nematodes and copepods. Mar. Ecol. Prog. Ser. 359, 145-150. https://doi.org/10.3354/meps07328

Rzeznik-Orignac, J., Fichet, D., 2012. Experimental estimation of assimilation rates of meiofauna feeding on ${ }^{14} \mathrm{C}$-labelled benthic diatoms. J. Exp. Mar. Bio. Ecol. 432-433, 179-185. https://doi.org/10.1016/j.jembe.2012.06.019

Rzeznik-Orignac, J., Fichet, D., Boucher, G., 2003. Spatio-temporal structure of the nematode assemblages of the Brouage mudflat (Marennes-Oléron, France). Estuar. Coast. Shelf Sci. 58, 77-88. https://doi.org/10.1016/S0272-7714(03)00061-1

Saint-Béat, B., Dupuy, C., Agogué, H., Carpentier, A., Chalumeau, J., Como, S., David, V., De Crignis, M., Duchêne, J.C., Fontaine, C., Feunteun, E., Guizien, K., Hartmann, H., Lavaud, J., Lefebvre, S., Lefrançois, C., Mallet, C., Montanié, H., Mouget, J.L., Orvain, F., Ory, P., Pascal, P.Y., Radenac, G., Richard, P., Vézina, A.F., Niquil, N., 2014. How does the resuspension of the biofilm alter the functioning of the benthos-pelagos coupled food web of a bare mudflat in Marennes-Oléron Bay (NE Atlantic)? J. Sea Res. 92, 144-157. https://doi.org/10.1016/j.seares.2014.02.003

Saint-Béat, B., Vézina, A.F., Asmus, R., Asmus, H., Niquil, N., 2013. The mean function provides robustness to linear inverse modelling flow estimation in food webs: A comparison of functions derived from statistics and ecological theories. Ecol. Modell. 258, 53-64. https://doi.org/10.1016/j.ecolmode1.2013.01.023 
Scharler, U.M., Baird, D., 2005. A comparison of selected ecosystem attributes of three South African estuaries with different freshwater inflow regimes, using network analysis. J. Mar. Syst. 56, 283-308. https://doi.org/10.1016/j.jmarsys.2004.12.003

Schratzberger, M., Ingels, J., 2018. Meiofauna matters: The roles of meiofauna in benthic ecosystems. J. Exp. Mar. Bio. Ecol. 502, 12-25. https://doi.org/10.1016/j.jembe.2017.01.007

Schückel, S., Sell, A.F., Kihara, T.C., Koeppen, A., Kröncke, I., Reiss, H., 2013. Meiofauna as food source for small-sized demersal fish in the southern North Sea. Helgol. Mar. Res. 67, 203-218. https://doi.org/10.1007/s10152-012-0316-1

Schückel, U., de Jonge, V., Ludovisi, A., Giebels, D., Horn, S., Niquil, N., Asmus, H., Asmus, R.M., Eulaers, I., Safi, G., Scharler, U.M., 2018. Use of coastal and estuarine food web models in policy making and management: The need for an entire ecosystem approach. https://doi.org/10.13140/RG.2.2.35173.09440

Schückel, U., Kröncke, I., 2013. Temporal changes in intertidal macrofauna communities over eight decades: A result of eutrophication and climate change. Estuar. Coast. Shelf Sci. 117, 210-218. https://doi.org/10.1016/j.ecss.2012.11.008

Schwinghamer, P., Hargrave, B., Peer, D., Hawkins, C.M., 1986. Partitioning of production and respiration among size groups of organisms in an intertidal benthic community. Mar. Ecol. Prog. Ser. 31, 131-142. https://doi.org/10.3354/meps031131

Sikora, J.P., Sikora, W.B., Erkenbrecher, C.W., Coull, B.C., 1977. Significance of ATP, carbon, and caloric content of meiobenthic nematodes in partitioning benthic biomass. Mar. Biol. 44, 7-14. https://doi.org/10.1007/BF00386899

Slobodkin, L.B., 1960. Ecological energy relationships at the population level. Am. Nat. 94, 213-236.

Smith, L.D., Coull, B.C., 1987. Juvenile spot (Pisces) and grass shrimp predation on meiobenthos in muddy and sandy substrata. J. Exp. Mar. Bio. Ecol. 105, 123-136. https://doi.org/10.1016/00220981(87)90167-5

Smith, S.M., Hoff, J.G., O’Neil, S.P., Weinsten, M.P., 1984. Community and trophic organization of nekton utilizing shallow marsh habitats, York River, Virginia. Fish. Bull. 82, 455-467.

Soetaert, K., van den Meersche, K., van Oevelen, D., 2017. Package "LimSolve."

Stock, B., Semmens, B., Ward, E., Parnell, A., Jackson, A., Phillips, D., 2018. MixSIAR: Bayesian mixing models in R.

Struski, C., Bacher, C., 2006. Preliminary estimate of primary production by phytoplankton in Marennes-Oléron Bay, France. Estuar. Coast. Shelf Sci. 66, 323-334. https://doi.org/10.1016/j.ecss.2005.09.007

Team, R.C., 2019. R: A language and environment for statistical computing.

Tecchio, S., Chaalali, A., Raoux, A., Tous Rius, A., Lequesne, J., Girardin, V., Lassalle, G., Cachera, M., Riou, P., Lobry, J., Dauvin, J.C., Niquil, N., 2016. Evaluating ecosystem-level anthropogenic impacts in a stressed transitional environment: The case of the Seine estuary. Ecol. Indic. 61, 833-845. https://doi.org/10.1016/j.ecolind.2015.10.036 
Thomas, C.R., Christian, R.R., 2001. Comparison of nitrogen cycling in salt marsh zones related to sea-level rise. Mar. Ecol. Prog. Ser. 221, 1-16. https://doi.org/10.3354/meps221001

Torchiano, M., 2019. Efficient effect size computation.

Vafeiadou, A.M., Materatski, P., Adão, H., De Troch, M., Moens, T., 2014. Resource utilization and trophic position of nematodes and harpacticoid copepods in and adjacent to Zostera noltii beds. Biogeosciences 11, 4001-4014. https://doi.org/10.5194/bg-11-4001-2014

van den Meersche, K., Soetaert, K., van Oevelen, D., 2009. xsample(): An R function for sampling linear inverse problems. J. Stat. Softw. 30, 128-129. https://doi.org/10.1002/wics.10

van der Heijden, L.H., Graeve, M., Asmus, R.M., Rzeznik-Orignac, J., Niquil, N., Bernier, Q., Guillou, G., Asmus, H., Lebreton, B., 2019. Trophic importance of microphytobenthos and bacteria to meiofauna in soft-bottom intertidal habitats: A combined trophic marker approach. Mar. Environ. Res. 149, 50-66. https://doi.org/10.1016/j.marenvres.2019.05.014

van der Heijden, L.H., Rzeznik-Orignac, J., Asmus, R.M., Fichet, D., Bréret, M., Kadel, P., Beaugeard, L., Asmus, H., Lebreton, B., 2018. How do food sources drive meiofauna community structure in softbottom coastal food webs? Mar. Biol. 165, 1-19. https://doi.org/10.1007/s00227-018-3419-7

van Oevelen, D., Soetaert, K., Middelburg, J.J., Herman, P.M.J., Moodley, L., Hamels, I., Moens, T., Heip, C.H.R., 2006. Carbon flows through a benthic food web: Integrating biomass, isotope and tracer data. J. Mar. Res. 64, 453-482. https://doi.org/10.1357/002224006778189581

van Oevelen, D., van den Meersche, K., Meysman, F.J.R., Soetaert, K., Middelburg, J.J., Vézina, A.F., 2010. Quantifying food web flows using linear inverse models. Ecosystems 13, 32-45. https://doi.org/10.1007/s10021-009-9297-6

Vézina, A.F., Platt, T., 1988. Food web dynamics in the ocean. I. Best-estimates of flow networks using inverse methods. Mar. Ecol. Prog. Ser. 42, 269-287. https://doi.org/10.3354/meps042269

Vilela, M.H., 1992. Mass culture and nutritional quality of the marine copepod Tigriopus brevicornis Müller. Bol. Inst. Nac. Invest. Pescas 17, 49-63.

Vizzini, S., Sarà, G., Michener, R.H., Mazzola, A., 2002. The role and contribution of the seagrass Posidonia oceanica (L.) Delile organic matter for secondary consumers as revealed by carbon and nitrogen stable isotope analysis. Acta Oecologica 23, 277-285. https://doi.org/10.1016/S1146-609X(02)01156-6

Vranken, G., Heip, C.H.R., 1986. The productivity of marine nematodes. Ophelia 26, 429-442.

Watanabe, T., Arakawa, T., Kitajima, C., Fukusho, K., Fujita, S., 1978. Nutritional quality of living feed from the viewpoint of essential fatty acids for fish. Bull. Japanse Soc. Sci. Fish. 44, 1223-1227.

Watanabe, T., Kitajima, C., Fujita, S., 1983. Nutritional values of live organisms used in Japan for mass propagation of fish: A review. Aquaculture 34, 115-143. https://doi.org/10.1016/0044-8486(83)90296$\mathrm{X}$

Wieser, W., 1953. Die Beziehungen zwischen Mundhöhlengestalt, Ernährungsweise und Vorkommen bei freilebenden marinen Nematoden. Ark. Zool. (Ser. 2) 4, 439-484.

Wulff, F., Field, J.G., Mann, K.H., 1989. Network analysis in marine ecology: methods and applications. Springer-Verlag, New-York, USA. 